\title{
๖The Importance of Convective Stage on Out-of-Cloud Convectively Induced Turbulence from High-Resolution Simulations
}

\author{
KATElyn A. BARBeR ${ }^{\mathrm{a}, \mathrm{b}}$ AND GRetchen L. MUlLendore ${ }^{\mathrm{a}}$ \\ ${ }^{a}$ University of North Dakota, Grand Forks, North Dakota, \\ ${ }^{\mathrm{b}}$ Pacific Northwest National Laboratory, Richland, Washington
}

(Manuscript received 24 February 2020, in final form 11 September 2020)

\begin{abstract}
Turbulence (clear-air, mountain wave, convectively induced) is an aviation hazard that is a challenge to forecast due to the coarse resolution ultilized in operational weather models. Turbulence indices are commonly used to aid pilots in avoiding turbulence, but these indices have been designed and calibrated for midlatitude clear-air turbulence prediction (e.g., the Ellrod index). A significant limitation with current convectively induced turbulence (CIT) prediction is the lack of storm stage dependency. In this study, six high-resolution simulations of tropical oceanic and midlatitude continental convection are performed to characterize the turbulent environment near various convective types during the developing and mature stages. Second-order structure functions, a diagnostic commonly used to identify turbulence in turbulence prediction systems, are used to characterize the probability of turbulence for various convective types. Turbulence likelihood was found to be independent of region (i.e., tropical vs midlatitude) but dependent on convective stage. The probability of turbulence increased near developing convection for the majority of cases. Additional analysis of static stability and vertical wind shear, indicators of turbulence potential, showed that the convective environment near developing convection was more favorable for turbulence production than mature convection. Near developing convection, static stability decreased and vertical wind shear increased. Vertical wind shear near mature and developing convection was found to be weakly correlated to turbulence intensity in both the tropics and the midlatitudes. This study emphasizes the need for turbulence avoidance guidelines for the aviation community that are dependent on convective stage.
\end{abstract}

KEYWORDS: Turbulence; Thunderstorms; Mesoscale forecasting; Numerical weather prediction/forecasting

\section{Introduction}

Out-of-cloud convectively induced turbulence (CIT) is an operational challenge to aviation as global flight routes increase and air space becomes more congested (Statista 2020). While numerous forecast guidance systems including real-time avoidance algorithms and preflight forecast systems like the Graphical Turbulence Product (GTG-2; Sharman and Pearson 2017; Pearson and Sharman 2017; Sharman et al. 2006) are in use and are frequently updated to provide pilots with more information, the complexity of CIT is not always depicted by these systems. To address the limitations of prediction systems and reduce the number of aviation encounters with convective hazards, the Federal Aviation Administration (FAA) has thunderstorm avoidance guidelines in place (FAA 2017). The most impactful guideline that influences flight routes and Air Traffic Control is the lateral avoidance of 20 miles $(\sim 32 \mathrm{~km})$ from severe convection. While the guidelines are based on empirical research of CIT in the midlatitudes, the same guidelines are also recommended by the FAA to be followed by U.S. airlines along tropical flight routes because of the limited understanding of tropical CIT. However, convective and

¿ Denotes content that is immediately available upon publication as open access.

Corresponding author: Katelyn A. Barber, katelyn.barber@pnnl.gov environmental properties are known to vary between the midlatitudes and tropics, from the strength, depth, and duration of convection, to the environmental shear and stability profiles (Vant-Hull et al. 2016; Frierson and Davis 2011; Wissmeier and Goler 2009; Frierson 2006; Liu and Zipser 2005; Yuter et al. 2005; Garstang and Fitzjarrald 1999; Chin et al. 1995; Saha and Singh 1972), each of which contribute to and influence the severity of potential aviation hazards.

The hazards to aviation caused by convection are also dependent on the type and stage of convection (Barber et al. 2019; Barber et al. 2018; Lane et al. 2003). However, variations in turbulence probability relative to convective type of stage are not addressed by current FAA guidelines; only the classification "severe convection" is mentioned. In other words, developing convection is a hazard not addressed by the FAA guidelines unless severe in intensity. Developing convection is a concern to aviation because it is generally difficult to forecast, especially timing and location. Therefore, accounting for developing convection results in limited confidence for in-flight planning without nowcasting products. In addition, without real-time observations of convection from satellite and ground-based radar systems, the pilot has to rely on visual cues of developing convection and proper usage of onboard radar.

High-resolution modeling is commonly used to examine small-scale processes that operational forecasting systems cannot resolve. CIT occurs across multiple scales from 10 to $1000 \mathrm{~m}$ (Lester 1994) and can impact aviation over $100 \mathrm{~km}$ 

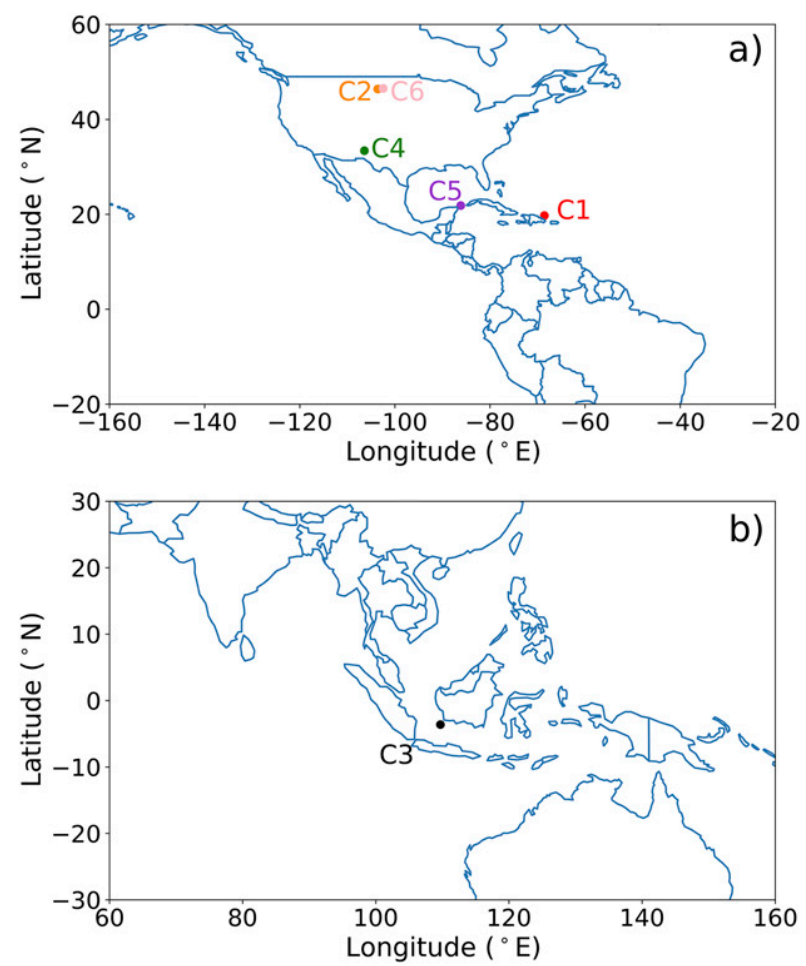

FIG. 1. Map of turbulence incidents in the (a) Western and (b) Eastern Hemispheres (red: -C1; orange: -C2; black: C3; green: C4; purple: C5; and pink: C6).

away from the source of convection (Barber et al. 2018; Lane et al. 2012), well past the FAA lateral avoidance distance of 20 miles $(\sim 32 \mathrm{~km})$. CIT is generally expressed as an empirical diagnostic or ensemble of diagnostics in operational forecasts (e.g., GTG-2, Ellrod index; Ellrod and Knapp 1992). Highresolution simulations allow for more in-depth analysis of convective processes that, in turn, produce turbulence, which aids in the development of turbulence avoidance procedures (Lane et al. 2012). These small-scale and temporally limited processes include the generation of convective gravity waves, enhancement of deformation zones along cloud boundaries, and enhancement of shear as convection penetrates the tropopause (Lane et al. 2003). An additional benefit of highresolution simulations is the more representative depiction of turbulence intensity (Barber et al. 2018). While high-resolution simulations of convection allow for further examination of the characteristics of turbulence and the relationship of convective intensity to turbulence, the majority of these simulations have been designed for midlatitude CIT (Barber et al. 2018; ZovkoRajak and Lane 2014; Kim and Chun 2012; Lane and Sharman 2008; Lane et al. 2003).

This study examines the influence of near-storm environmental conditions on the distribution of out-of-cloud CIT for tropical and midlatitude convective simulations to determine if the probability of experiencing CIT varies between storm stages and regions. More specifically, this study will investigate if the environmental conditions near various convective types in the midlatitudes and tropics are similar and have comparable turbulence probabilities. Six encounters of moderate to severe CIT in various convective regimes are used as high-resolution simulation case days and compared to observations (Fig. 1). Storm and environmental characteristics that are indicative of turbulence potential are presented.

\section{Methodology}

In this study, 24-30-h simulations of midlatitude and tropical convection are made using the Advanced Research WRF (ARW) Model, version 3.7 (Skamarock and Klemp 2008). All simulations are initialized with ERA-Interim global dataset (http://www.ecmwf.int/en/research/climate-reanalysis/ era-interim) at various times (Table 1). One parent and two nested domains are used in these simulations with a horizontal grid spacing of $4.5 \mathrm{~km}, 1.5 \mathrm{~km}$, and $500 \mathrm{~m}$ from the outer to inner domains (Fig. 2). All domains have 100 vertical levels. The vertical grid spacing between 8 and $12 \mathrm{~km}$ is approximately $325 \mathrm{~m}$. The number of vertical levels is decreased to 65 (approximately $550 \mathrm{~m}$ grid spacing between 8 and $12 \mathrm{~km}$ ) for 4 June 2018 (C4), due to a numerical instability issue in the simulation, likely influenced by the terrain. A $10-\mathrm{km}$ damping layer is used at the model top that is set to approximately $30 \mathrm{~km}$ $(10 \mathrm{hPa})$. This study uses the WDM6 microphysical parameterization and the Mellor-Yamada-Janjić (MYJ) planetary boundary layer scheme (additional parameterization information is provided in Table 2) for all simulations except 10 July 1997 (C2) and 3 August 2009 (C1). These particular cases use the Morrison microphysical scheme as it produces convection that is in better agreement with observed morphology after subjective testing of various microphysical schemes (not shown). Otherwise, the parameterizations were kept consistent for the midlatitude and tropical simulations in order to reduce

TABLE 1. Initialization time, analysis period, and time period of increased temporal resolution for each simulated case. Odd-numbered cases are tropical and even-numbered cases are midlatitude.

\begin{tabular}{cllll}
\hline \hline Case identifier & Case day & Initialization time & Analysis period & Period of increased temporal resolution \\
\hline C1 & 3 Aug 2009 & 1200 UTC 2 Aug & 1800-1800 UTC & 1200-1400 UTC 3 Aug \\
C2 & 10 Jul 1997 & 0000 UTC 10 Jul & 0600-0600 UTC & 1800-2300 UTC 10 Jul \\
C3 & 27 Dec 2014 & 0000 UTC 27 Dec & 0600-0600 UTC & 0000-0400 UTC 28 Dec \\
C4 & 4 Jun 2018 & 1200 UTC 3 Jun & $1800-0600$ UTC & $1900-2300$ UTC 3 Jun \\
C5 & 20 Jun 2017 & 0000 UTC 20 Jun & 0600-0600 UTC & 1200-1800 UTC 20 Jun \\
C6 & 29 Jun 2018 & 1200 UTC 29 Jun & $1800-1800$ UTC & 1800 UTC 29 Jun-0000 UTC 30 Jun \\
\hline
\end{tabular}



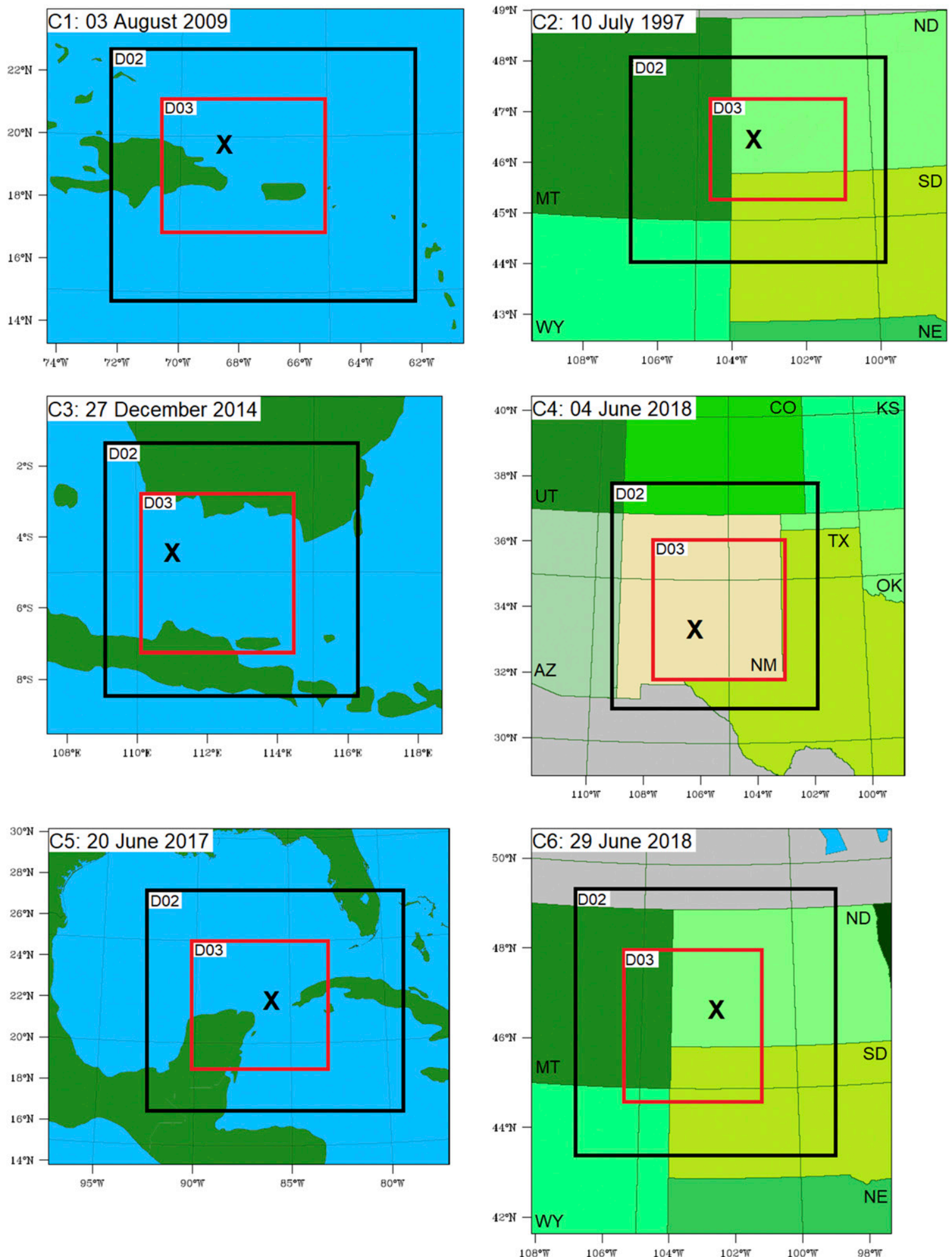

FIG. 2. Model domain of case studies. Innermost nest (D03) has a horizontal grid spacing of $500 \mathrm{~m}$. The "X" symbol represents the location of the turbulence encounter. 
TABLE 2. Parameterizations used in the six simulations.

\begin{tabular}{ll}
\hline \multicolumn{1}{c}{ Model physics } & \multicolumn{1}{c}{ Model setup } \\
\hline Microphysics & WDM6 (Lim and Hong 2010)/Morrison (C1 and C2; Morrison et al. 2009) \\
Planetary boundary layer & MYJ (Janjić 1994) \\
Surface layer & Eta similarity (Monin and Obukhov 1954, Janjić 1994, 1996, 2002) \\
Land surface & Noah (Tewari et al. 2004) \\
Shortwave radiation & Dudhia (Dudhia 1989) \\
Longwave radiation & RRTM LW (Mlawer et al. 1997) \\
\hline
\end{tabular}

uncertainty in the turbulence response due to differences in physics schemes. While a full investigation of the sensitivity to parameterizations is beyond the scope of this study, we are confident that the comparative results presented in this study (e.g., tropical versus midlatitude and developing stage versus mature stage) are robust based on prior simulations of CIT conducted (Barber 2015, Barber et al. 2018, Barber 2019). Simulation output is saved every $10 \mathrm{~min}$ during periods of convective activity to examine convective development, maturity, and dissipation of individual convective cells (Table 1).

Turbulence is identified in this study using second-order structure functions following the methodology implemented in Barber et al. (2019). Structure functions are an estimation method for eddy dissipation rate $(\mathrm{EDR}, \varepsilon)$ in the inertial range (Kolmogorov 1941; Frehlich and Sharman 2004a,b; Sharman et al. 2006) and have had success for turbulence identification in many studies (Barber et al. 2019; Sharman and Pearson 2017; Pearson and Sharman 2017; Frehlich and Sharman 2010). Second-order structure functions (hereafter, $\mathrm{SF})$, are computed as

$$
\begin{aligned}
& D_{l l}(u)=\left[u_{l}(i)-u_{l}(i+\Delta s)\right]^{2}, \\
& D_{l l}(v)=\left[v_{l}(i)-v_{l}(i+\Delta s)\right]^{2}, \\
& D_{t t}(u)=\left[u_{t}(i)-u_{t}(i+\Delta s)\right]^{2}, \\
& D_{t t}(v)=\left[v_{t}(i)-v_{t}(i+\Delta s)\right]^{2},
\end{aligned}
$$

in both the transverse $(t t)$ and longitudinal $(l l)$ directions. In Eqs. (1)-(4), $i$ is the grid index, $u_{t, l}$ and $v_{t, l}$ are the $u$-component and $v$-component of wind along the transverse and longitudinal directions, and $s$ is a separation distance expressed in units of spatial grid steps $(d x)$.

The four $D_{l l, t t}$ components ( $u$-longitudinal, $v$-longitudinal, $u$-transverse, and $v$-transverse) in Eqs. (5) and (6) are averaged together [represented by $\left\langle D_{s}\right\rangle$ in Eq. (7)] after manipulation of Eqs. (5) and (6) to solve for $\varepsilon^{1 / 3}$ [Eq. (7)]. In other words, $D_{l l, t t}$ from Eqs. (1)-(4) are inserted in Eqs. (5) and (6), and the remaining terms are moved to the left-hand side of the equations, leaving the $\varepsilon$ term on the right-hand side. The value on the lefthand side of the manipulated equations for the four components are then averaged together. In this formulation $C_{k}$ equals 2 (Frehlich and Sharman 2010). A value of 7 is chosen for $s$ because it mirrors the spectral resolution of the model advection scheme particularly well (Muñoz-Esparza et al. 2018; Skamarock 2004):

$$
\begin{aligned}
D_{l l} & =C_{k} \varepsilon^{2 / 3} \Delta s^{2 / 3}, \\
D_{t t} & =\frac{4}{3} C_{k} \varepsilon^{2 / 3} \Delta s^{2 / 3}, \\
\varepsilon^{1 / 3} & =\left\langle D_{s}\right\rangle^{1 / 2} .
\end{aligned}
$$

Turbulence intensity is determined from the second-order structure functions using the thresholds provided in Table 3 (values for a medium-sized aircraft). Additional indices such as subgrid-scale eddy dissipation rate computed from turbulent kinetic energy (TKE) and Richardson number were examined for the six cases, but were found to have significant limitations (see Barber 2019).

In-cloud and out-of-cloud turbulence are differentiated using the mixing ratios of cloud ice and cloud water. A mixing ratio of greater than or equal to $0.1 \mathrm{~g} \mathrm{~kg}^{-1}$ defines in cloud and less than $0.1 \mathrm{~g} \mathrm{~kg}^{-1}$ defines out of cloud (Lane et al. 2003). When SF are computed, the grid point itself and all points considered in the calculation must be out of cloud. An 18-dBZ threshold for simulated radar reflectivity is used to determine the echo-top height, which is used as a proxy for storm height. In this study, individual convective objects (CO) are defined as contiguous regions with echo tops greater than $8 \mathrm{~km}$ in height. The COs are followed through time using the object's centroid location. A new object is defined if the centroid location of a previous convective object has changed by more than $10 \mathrm{~km}$ (horizontally) in a 10-min period. Vertical velocity is a common convective variable that can be used to describe convective stage (Hamada and Takayabu 2016; Schumacher et al. 2015; Katzwinkel et al. 2014; May and Rajopadhyaya 1999). Additional information on how convective stage has been defined in past studies can be found in Barber et al. (2019). The distinction between developing convection and mature convection in this study follows the methodology of Barber et al. (2019). Developing convection is defined as a convective object in which the simulated maximum vertical velocity for that object is less than the 90th percentile of all maximum vertical

TABLE 3. Turbulence intensity thresholds as determined from the cubed root of eddy dissipation rate ( $\varepsilon$; Sharman and Pearson 2017) for a medium-sized aircraft.

\begin{tabular}{cc}
\hline \hline Turbulence intensity & $\varepsilon^{1 / 3}\left(\mathrm{~m}^{2 / 3} \mathrm{~s}^{-1}\right)$ \\
\hline Light & $0.15-0.22$ \\
Moderate & $0.22-0.34$ \\
Severe & $\geq 0.34$ \\
\hline
\end{tabular}


TABLE 4. Location and time of the aviation turbulence encounters. Odd-numbered cases are tropical and even-numbered cases are midlatitude.

\begin{tabular}{ccc}
\hline \hline Case identifier & Time of encounter & Location of encounter \\
\hline C1 & 0755 UTC & $19.73^{\circ} \mathrm{N},-68.55^{\circ} \mathrm{E}$ \\
C2 & 2141 UTC & $46.4^{\circ} \mathrm{N},-103.6^{\circ} \mathrm{E}$ \\
C3 & $2317 \mathrm{UTC}$ & $3.62^{\circ} \mathrm{S}, 109.70^{\circ} \mathrm{E}$ \\
C4 & $0108 \mathrm{UTC}$ & $33.4^{\circ} \mathrm{N},-106.4^{\circ} \mathrm{E}$ \\
C5 & $1651 \mathrm{UTC}$ & $21.84^{\circ} \mathrm{N},-86.16^{\circ} \mathrm{E}$ \\
C6 & $2257 \mathrm{UTC}$ & $46.51^{\circ} \mathrm{N},-102.46^{\circ} \mathrm{E}$ \\
\hline
\end{tabular}

velocities of that object's lifespan and less than the maximum vertical velocity of the following time period. The 90th percentile of maximum vertical velocities was chosen based on analysis of vertical velocity distributions for convective objects with time, echo-top heights, and simulated lightning production (not shown). To determine if turbulence is associated with developing convection or mature convection, distance is calculated between the turbulent grid cell and the boundaries of the convective object.
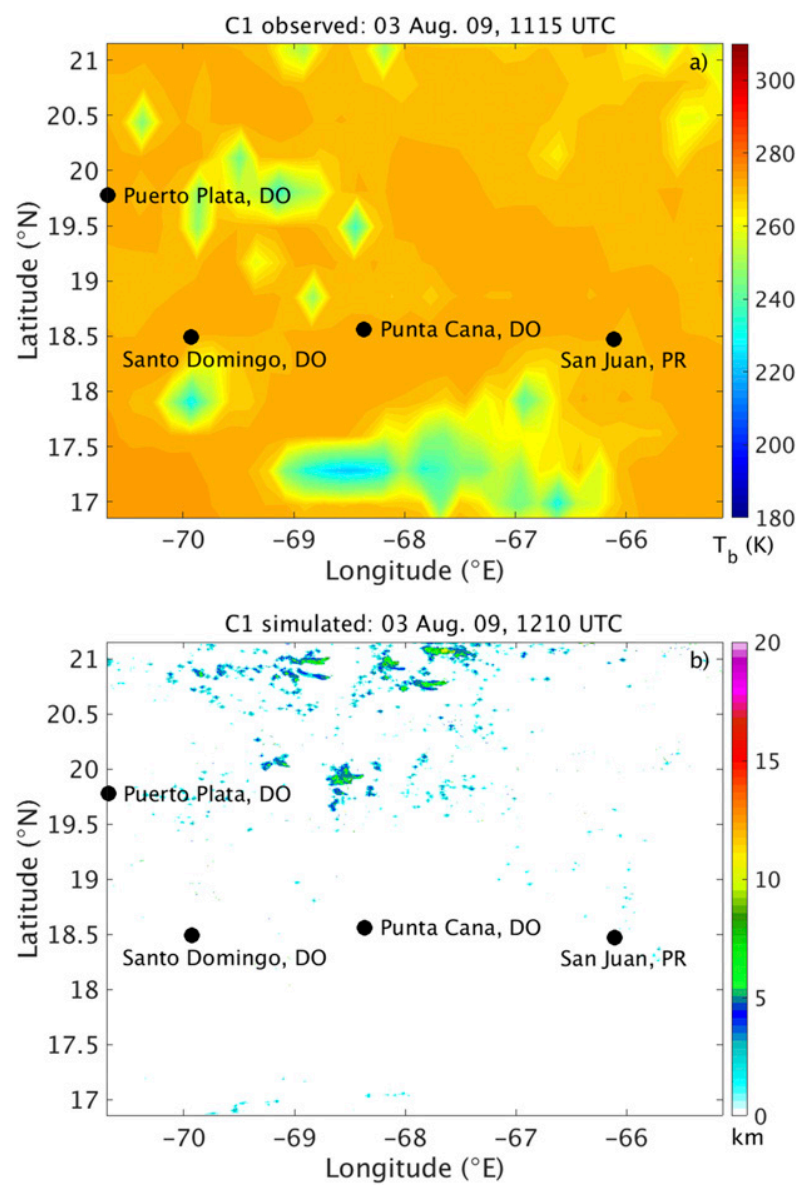

FIG. 3. Observed brightness temperature from (a) GOES-12 and (b) simulated echo-top heights for $\mathrm{C} 1$. Time of analysis provided in the figure.
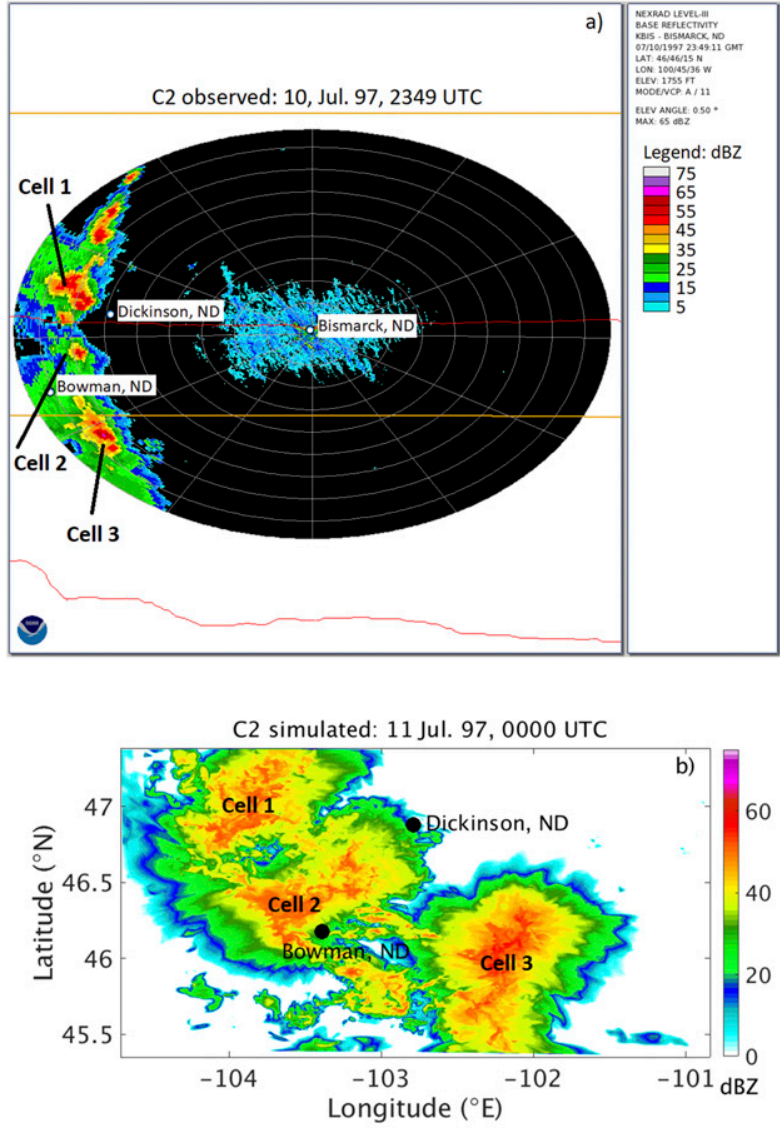

FIG. 4. Observed radar reflectivity values $\left({ }^{\circ} 0.5\right)$ from (a) KBIS and (b) simulated maximum radar reflectivity values for $\mathrm{C} 2$. Time of analysis provided in the figure.

Static stability and vertical wind shear between 8 and $12 \mathrm{~km}$ (representing the typical cruising altitudes of commercial aircraft) are used to characterize the near-storm environment around convection in terms of turbulence potential. Low static stability and/or high vertical wind shear are favorable conditions for growth of instabilities (e.g., Kelvin-Helmholtz waves, gravity waves); this growth can then lead to instability breakdown (e.g., wave breaking) and turbulence production. The computations of static stability $\left(N^{2}\right.$; square of Brunt Vaisala frequency) and vertical wind shear $\left(S_{v}^{2}\right)$ are provided below:

$$
N^{2}=\frac{g}{\theta} \frac{\partial \theta}{\partial z}
$$

where $g$ is gravity, $\theta$ is potential temperature $(\mathrm{K})$, and $\partial \theta / \partial z$ is the change of potential temperature with height.

The vertical wind shear $S_{v}^{2} \sqrt{2}$ is defined as

$$
S_{v}^{2}=\left(\left|\frac{\partial u}{\partial z}\right|^{2}+\left|\frac{\partial v}{\partial z}\right|^{2}\right),
$$

where $u$ and $v$ are the horizontal components of velocity $\left(\mathrm{m} \mathrm{s}^{-1}\right)$, and $z$ is height $(\mathrm{m})$. 

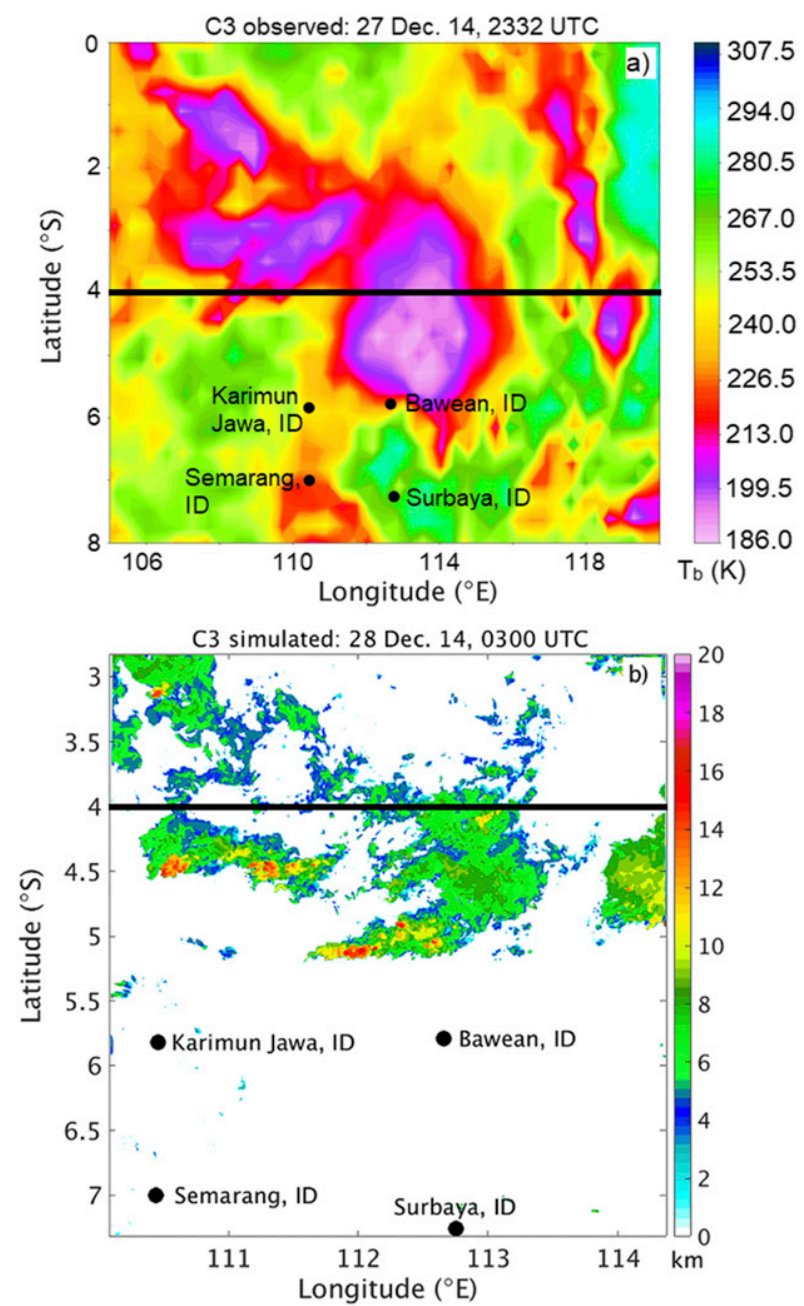

FIG. 5. Observed brightness temperature from (a) MTSAT-2 and (b) simulated echo-top heights for C3. Time of analysis provided in figure. The black line at $4^{\circ} \mathrm{S}$ is included to illustrate the location biases between the observed and simulated convection.

\section{Overview of case days and simulated convection}

In this section, details regarding six aviation encounters of convectively induced turbulence are summarized. Table 4 provides a summary of the time and location of the turbulence encounters (see Fig. 1 for geographical locations). Observed convective features compared to simulated convection for each case day are provided in Figs. 3-8. Simulated echo-top heights and second-order structure functions (SF, values for a medium-sized aircraft) for the inner domain of each case day are provided in Figs. 9-14 as depictions of areal coverage and turbulence intensity in the region of interest.

\section{a. 3 August 2009 (C1)}

On 3 August 2009, a Boeing 767 encountered severe turbulence while flying to the northeast of the Dominican Republic $\left(19.73^{\circ} \mathrm{N},-68.55^{\circ} \mathrm{E}\right)$ at 0755 UTC. Convection in the
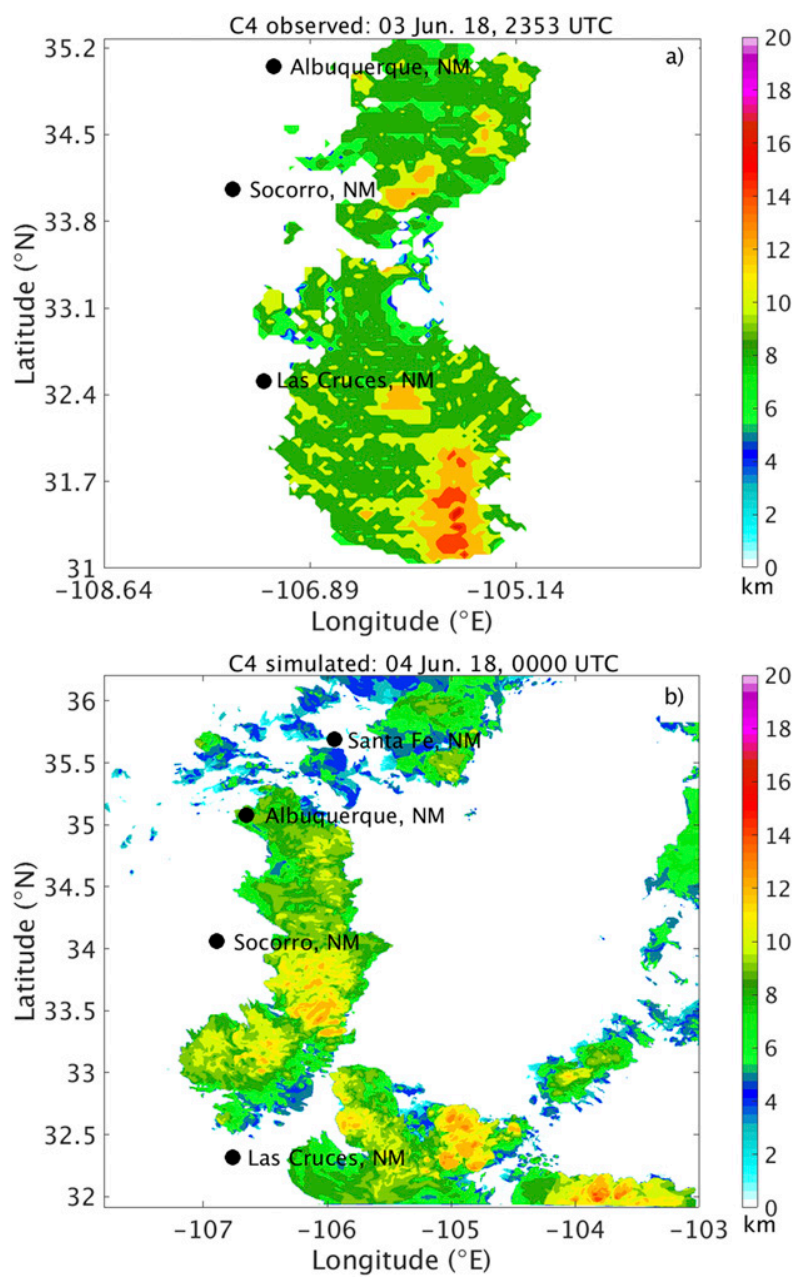

FIG. 6. Observed echo-top heights from (a) KEPZ and (b) simulated echo-top heights for $\mathrm{C} 4$. Time of analysis provided in the figure.

area was rapidly developing and the aircraft flew through the top of a convective updraft (Monette and Sieglaff 2014; Ahmad and Proctor 2011; NTSB 2011; Vasquez 2009) causing 33 minor injuries. Vertical accelerations experienced by the aircraft ranged from -1 to $2 \mathrm{~g}$ between 11 and $11.5 \mathrm{~km}$ in altitude for no more than $8 \mathrm{~s}$. While convection was forecasted for this region, turbulence was not predicted along the aircraft's flight path by the deformation-vertical shear index (see Knox et al. 2008 for details pertaining to the deformation-vertical shear index). Although turbulence was not predicted, the captain was aware of convection in the area and had begun safety procedures to limit hazards associated with convection (NTSB 2011). A meteorological overview of this case day was compiled by Vasquez (2009). In short, the area in which the flight experienced turbulence was influenced by the Bermuda high with weak winds aloft, but instability was present in sounding observations between 8 and $12 \mathrm{~km}$. Convection was very isolated, extending past $11 \mathrm{~km}$ in very few cells. This convection was likely enhanced by a tropical easterly wave propagating 

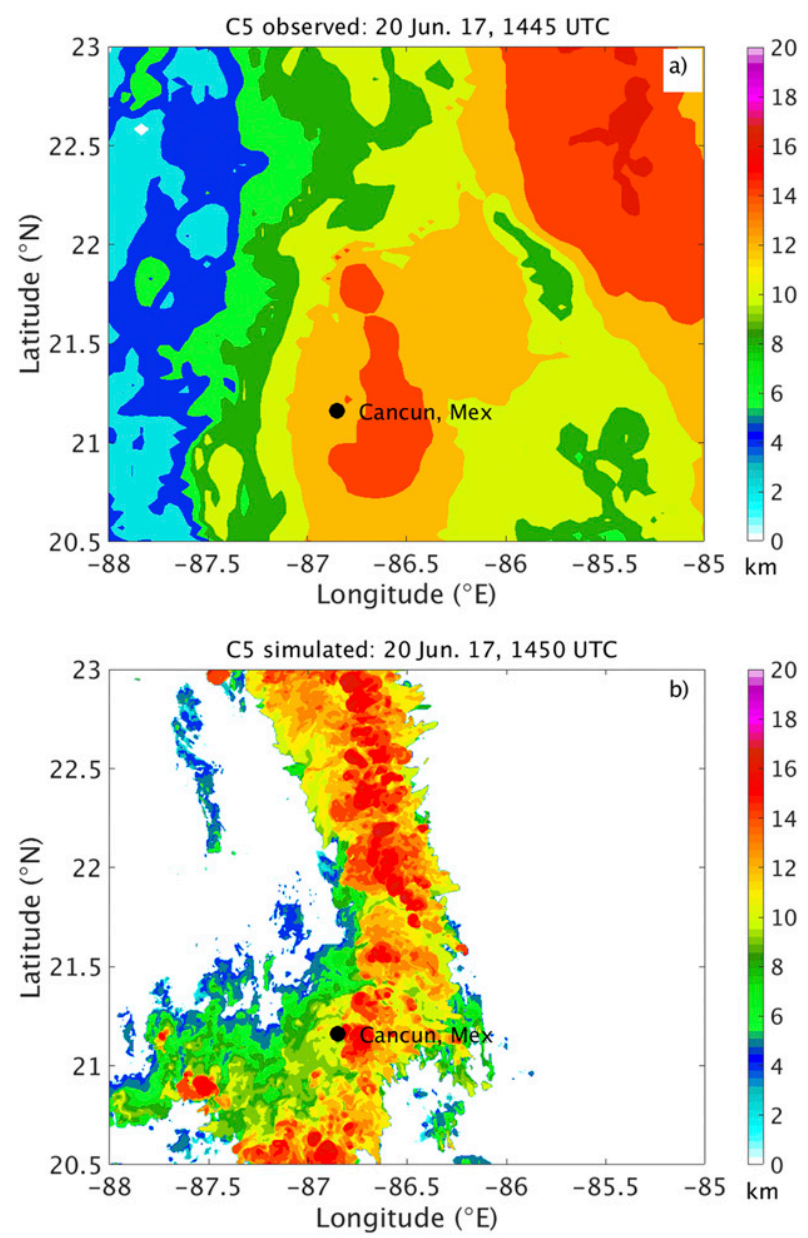

FIG. 7. (a) Observed cloud-top heights from the Convective Diagnosis Oceanic Algorithm (Kessinger 2017; Kessinger et al. 2008) and (b) simulated echo-top heights for C5. Time of analysis provided in the figure.

through the region or an upper level trough that was also present. Satellite observations later confirmed the aircraft had penetrated a developing convective cell.

Isolated cells with simulated radar reflectivity values greater than $35 \mathrm{dBZ}$ at $2 \mathrm{~km}$ initiate over the land features of the Dominican Republic and Haiti, due to diurnal heating $3 \mathrm{~h}$ into the simulation on 2 August 2009. Oceanic convection initiates $9 \mathrm{~h}$ later at 0000 UTC 3 August as weak isolated cells (radar reflectivity values less than $50 \mathrm{dBZ}$ ) in the northeast region of the inner domain. Oceanic convection persists north of the Dominican Republic for the next $18 \mathrm{~h}$ of simulation and reaches maximum intensity near 1340 UTC as convective cells propagate westward. Simulated echo-top heights over the ocean are less than $8 \mathrm{~km}$ until after 1200 UTC when the depth of three convective cells northeast of the Dominican Republic exceed $10 \mathrm{~km}$. The morphology and depth of simulated convection resembles the observed convection (weak, sporadic, isolated cells; Fig. 3), especially to the east and north of Puerto Plata. Convective available potential energy (CAPE) in the domain was greater than $2000 \mathrm{~J} \mathrm{~kg}^{-1}$ and the tropopause was
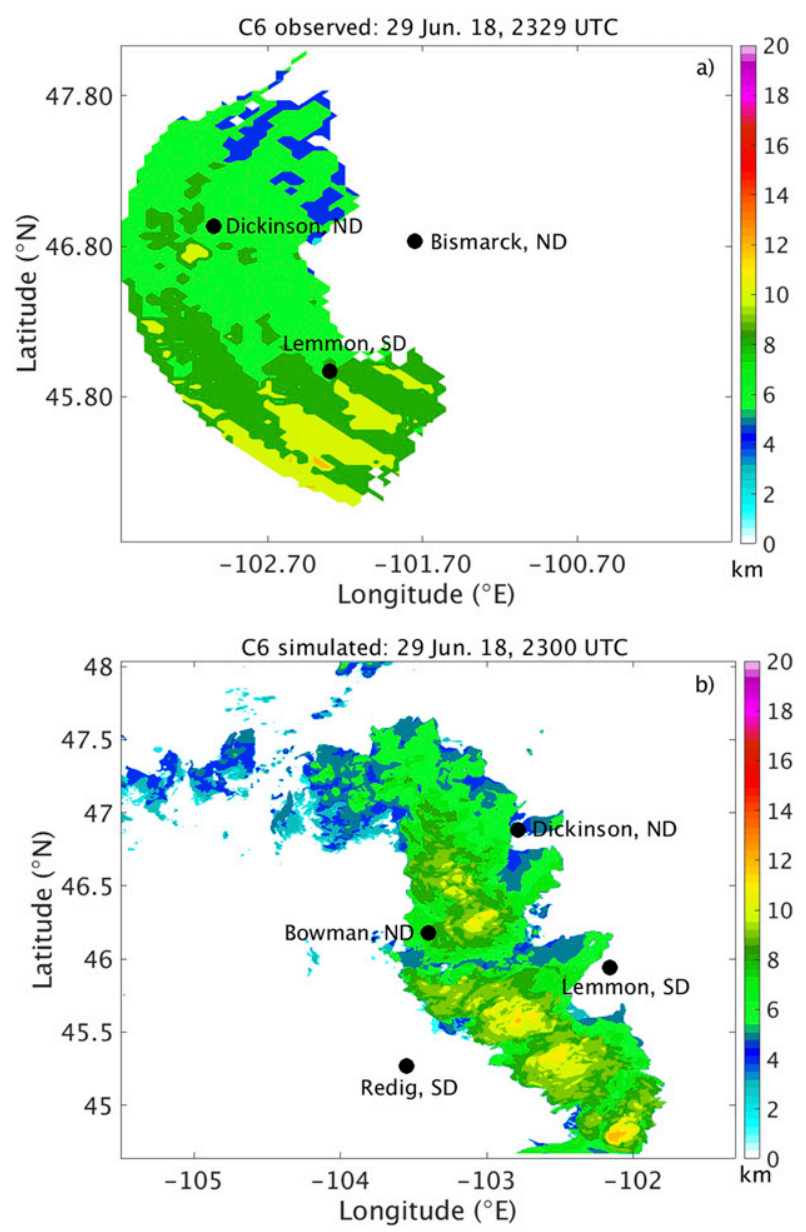

FIG. 8. Observed echo-top heights from (a) KBIS and (b) simulated echo-top heights. Time of analysis provided in the figure.

near $13.5 \mathrm{~km}$. Compared to radar observations from San Juan, the simulated convection over the ocean initiates approximately $4 \mathrm{~h}$ later than observations, but the location of the simulated convective cell that likely influenced the aircraft is within $50 \mathrm{~km}$ of observations. The time period of 1200-1400 UTC 3 August will be used to analyze the influence of convective stage on turbulence (section 4 ) as it compares well against observations, where cells are increasing in depth.

Simulated echo-top heights and maximum second-order structure functions (SF) at 1340 UTC are shown in Fig. 9 between 8 and $12 \mathrm{~km}$, as the turbulence encounter was near $10 \mathrm{~km}$, and observed convection was extending past the altitude of the aircraft. Turbulence intensity predicted by SF is light or null out of cloud mainly to the south of the region of interest. However, SF do indicate moderate or greater turbulence between 8 and $12 \mathrm{~km}$ in the simulated convective cell most similar to the observed cell at 1400 UTC. In terms of prediction, SF would have been a beneficial diagnostic to aviation flying near developing convective cells. 
TABLE 5. Mean, median, maximum, and minimum static stability $\left(N^{2}\right.$; units: $\left.\mathrm{s}^{-2}\right)$ near mature (MCO) and developing (DCO) convection. Odd-numbered cases are tropical and even-numbered cases are midlatitude.

\begin{tabular}{cccccc}
\hline \hline Case identifier & MCO mean (median) $N^{2}$ & MCO max (min) $N^{2}$ & DCO mean (median) $N^{2}$ & DCO max (min) $N^{2}$ \\
\hline C1 & $7.98 \times 10^{-5}\left(7.88 \times 10^{-5}\right)$ & $1.02 \times 10^{-4}\left(6.33 \times 10^{-5}\right)$ & $7.70 \times 10^{-5}\left(7.62 \times 10^{-5}\right)$ & $9.19 \times 10^{-5}\left(6.87 \times 10^{-5}\right)$ \\
C2 & $1.57 \times 10^{-4}\left(1.59 \times 10^{-4}\right)$ & $2.66 \times 10^{-4}\left(3.01 \times 10^{-5}\right)$ & $1.39 \times 10^{-4}\left(1.42 \times 10^{-4}\right)$ & $2.23 \times 10^{-4}\left(3.40 \times 10^{-5}\right)$ \\
C3 & $7.41 \times 10^{-5}\left(7.43 \times 10^{-5}\right)$ & $9.75 \times 10^{-5}\left(4.58 \times 10^{-5}\right)$ & $7.30 \times 10^{-5}\left(7.33 \times 10^{-5}\right)$ & $8.47 \times 10^{-5}\left(6.18 \times 10^{-5}\right)$ \\
C4 & $1.35 \times 10^{-4}\left(1.31 \times 10^{-4}\right)$ & $3.07 \times 10^{-4}\left(8.78 \times 10^{-6}\right)$ & $1.23 \times 10^{-4}\left(1.22 \times 10^{-4}\right)$ & $2.74 \times 10^{-4}\left(1.56 \times 10^{-5}\right)$ \\
C5 & $7.32 \times 10^{-5}\left(7.26 \times 10^{-5}\right)$ & $1.08 \times 10^{-4}\left(4.03 \times 10^{-5}\right)$ & $7.33 \times 10^{-5}\left(7.25 \times 10^{-5}\right)$ & $9.76 \times 10^{-5}\left(5.09 \times 10^{-5}\right)$ \\
C6 & $1.86 \times 10^{-4}\left(1.85 \times 10^{-4}\right)$ & $2.77 \times 10^{-4}\left(5.16 \times 10^{-5}\right)$ & $1.63 \times 10^{-4}\left(1.58 \times 10^{-4}\right)$ & $2.46 \times 10^{-4}\left(7.94 \times 10^{-5}\right)$ \\
\hline
\end{tabular}

\section{b. 10 July 1997 (C2)}

On 10 July 1997, at approximately 2141 UTC, a Boeing 757 encountered severe turbulence while out of cloud flying southwest of Dickinson, ND $\left(46.4^{\circ} \mathrm{N},-103.6^{\circ} \mathrm{E}\right)$ at $2141 \mathrm{UTC}$. The aircraft was navigating between numerous convective cells that were extending higher than the altitude of the aircraft $(11.2 \mathrm{~km})$ near the time of the incident (NTSB 1997). The aircraft passed over a developing convective cell that was located between two mature convective cells (Fig. 4), causing 22 injuries. As was the case for C1, convection was forecasted in the region, but turbulence was not predicted along the flight path. The pilot had warned the passengers of possible turbulence when convection was in the region, but the "FASTEN SEATBELT" sign was not illuminated. This particular case has been examined with numerical simulations in Lane et al. (2003) in which a brief meteorological overview is provided. Convection was initiated by a frontal system that was associated with a prefrontal trough. The region was favorable for convective activity as CAPE was greater than $3500 \mathrm{~J} \mathrm{~kg}^{-1}$. The tropopause was near $11 \mathrm{~km}$.

Simulated convection on 10 July 1997 initiates in the domain at 2000 UTC and develops into two intense convective cells with $2-\mathrm{km}$ simulated radar reflectivity values exceeding $55 \mathrm{dBZ}$ over the next $4 \mathrm{~h}$ of simulation time. Three individual simulated convective features (two more intense and one weaker) are present in the domain at 2200 UTC (similar convective morphology as found in Lane et al. 2003). By 2300 UTC, all three simulated cells have increased in strength and echo-top heights exceed $12 \mathrm{~km}$ (tropopause is also near $12 \mathrm{~km}$ ). The convective cell that likely is associated with the turbulence encounter rapidly increases in vertical extent and areal coverage from 2200 to 2300 UTC, less than $1 \mathrm{~h}$ after observations indicate (labeled Cell 2 in Fig. 4). CAPE in the model domain is greater than $3000 \mathrm{~J} \mathrm{~kg}^{-1}$. Figure 4 shows the convective cells observed from the KBIS radar near 0000 UTC and the simulated cells also at 0000 UTC. Note this time is displayed because it is a time close to the turbulence encounter and the convection has moved into the KBIS radar domain. The northern cell (labeled Cell 1 in Fig. 4) is to the northwest of Dickinson, ND in both the model and observations. The cell closest to Dickinson, ND (labeled Cell 2 in Fig. 4) is much stronger in the simulations than in observations at 0000 UTC (recall this cell strengthens rapidly). Last, the southern cell (labeled Cell 3 in Fig. 4) is farther east in the simulations than in observations. The time period of 1800-2300 UTC 10 July will be used to analyze the influence of convective stage on turbulence (section 4) as the morphology of simulated convection compares well against observations, where the suspect cell is rapidly increasing in vertical depth.

Simulated echo-top heights and maximum SF at 1340 UTC are shown in Fig. 10. Due to the differences in observed and simulated convective height, the turbulence diagnostics are evaluated between 14 and $16 \mathrm{~km}$ to be representative of an aircraft flying above a convective cell that is rapidly developing. The height range of $2 \mathrm{~km}$ is also applicable to the vertical envelope of turbulence above convection $(1-3 \mathrm{~km}$; Lane et al. 2003). SF diagnose severe turbulence before the convective cell reaches a height of $13 \mathrm{~km}$ and continues to indicate severe turbulence as the cell increases in height. SF do predict turbulence of appropriate intensity above the convective cell and distance away from convection (within $50 \mathrm{~km}$ of convection). SF would have been a beneficial predictor of turbulence intensity and areal coverage for this convective case.

\section{c. 27 December 2014 (C3)}

On 27 December 2014, at approximately 2317 UTC, an Airbus A320 flying at $9.75 \mathrm{~km}$ went into an unrecoverable aerodynamic stall over the Java Sea $\left(3.62^{\circ} \mathrm{S}, 109.70^{\circ} \mathrm{E}\right)$ due to

TABLE 6. Mean, median, maximum, and minimum vertical wind shear $\left(S_{v}^{2}\right.$; units, $\left.\mathrm{s}^{-2}\right)$ near mature (MCO) and developing (DCO) convection. Odd-numbered cases are tropical and even-numbered cases are midlatitude.

\begin{tabular}{ccccc}
\hline \hline Case identifier & MCO mean (median) $S_{v}^{2}$ & MCO max (min) $S_{v}^{2}$ & DCO mean (median) $S_{v}^{2}$ & DCO max (min) $S_{v}^{2}$ \\
\hline C1 & $7.67 \times 10^{-8}\left(3.29 \times 10^{-8}\right)$ & $1.02 \times 10^{-5}\left(5.69 \times 10^{-10}\right)$ & $1.05 \times 10^{-7}\left(8.69 \times 10^{-8}\right)$ & $7.36 \times 10^{-7}\left(7.39 \times 10^{-9}\right)$ \\
C2 & $1.42 \times 10^{-6}\left(2.08 \times 10^{-7}\right)$ & $3.13 \times 10^{-4}\left(7.85 \times 10^{-10}\right)$ & $7.00 \times 10^{-6}\left(3.91 \times 10^{-6}\right)$ & $2.17 \times 10^{-4}\left(5.82 \times 10^{-8}\right)$ \\
C3 & $1.14 \times 10^{-7}\left(7.64 \times 10^{-8}\right)$ & $1.21 \times 10^{-5}\left(2.21 \times 10^{-9}\right)$ & $2.49 \times 10^{-7}\left(1.61 \times 10^{-7}\right)$ & $5.01 \times 10^{-6}\left(8.85 \times 10^{-9}\right)$ \\
C4 & $5.73 \times 10^{-7}\left(1.06 \times 10^{-7}\right)$ & $2.01 \times 10^{-4}\left(1.65 \times 10^{-10}\right)$ & $4.02 \times 10^{-6}\left(1.52 \times 10^{-6}\right)$ & $1.78 \times 10^{-4}\left(5.71 \times 10^{-9}\right)$ \\
C5 & $1.60 \times 10^{-7}\left(7.53 \times 10^{-8}\right)$ & $3.74 \times 10^{-5}\left(1.82 \times 10^{-9}\right)$ & $8.54 \times 10^{-7}\left(4.86 \times 10^{-7}\right)$ & $1.67 \times 10^{-5}\left(8.21 \times 10^{-9}\right)$ \\
C6 & $7.82 \times 10^{-7}\left(1.18 \times 10^{-7}\right)$ & $8.48 \times 10^{-5}\left(1.96 \times 10^{-10}\right)$ & $4.44 \times 10^{-6}\left(2.76 \times 10^{-6}\right)$ & $7.84 \times 10^{-5}\left(8.94 \times 10^{-8}\right)$ \\
\hline
\end{tabular}



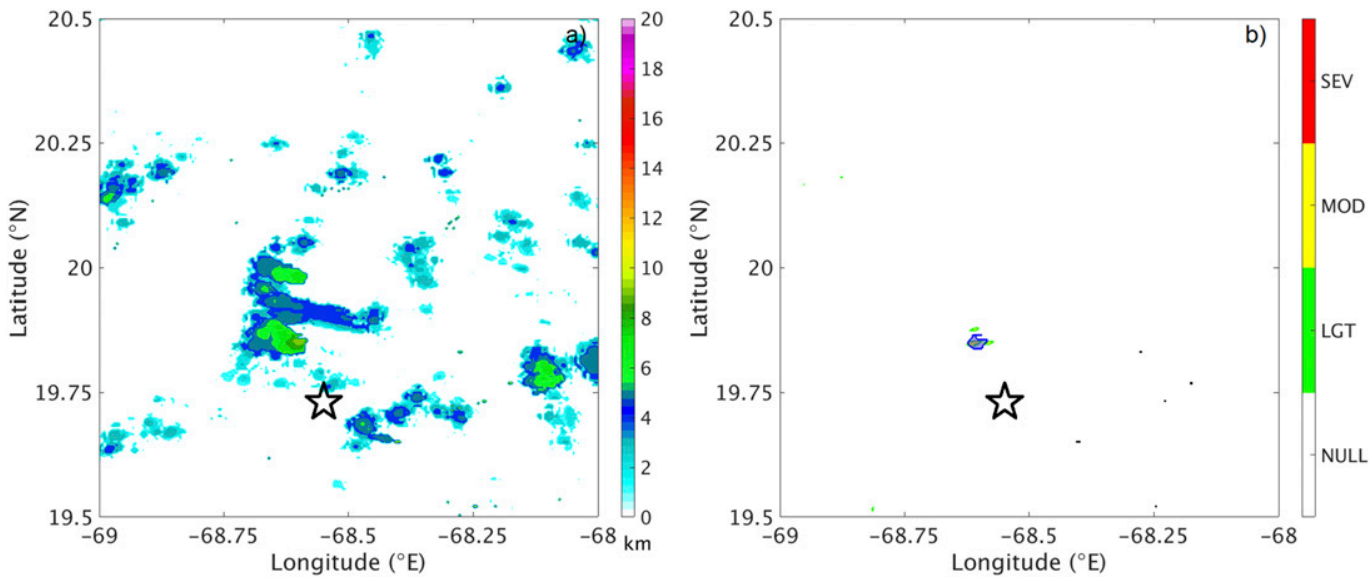

FIG. 9. (a) Simulated echo-top heights and (b) maximum second-order structure functions at 1340 UTC 3 Aug 2009 (C1) between 8 and $12 \mathrm{~km}$. Echo tops greater than $8 \mathrm{~km}$ are shown in (b) as blue contours (and shading) and the black star represents the location of the aircraft at 0755 UTC.

pilot error (KNKT 2015). Convection was present along the flight route and pilots had requested numerous altitude changes in order to avoid convection. The flight path was through a region with active convection and the predetermined flight altitudes were turbulent, suggesting prediction systems were underestimating turbulence intensity and convective hazards. A squall line was present in the region propagating westward and echo-top heights varied between 7.3 and $13.4 \mathrm{~km}$. The convection was likely caused by the migration of the intertropical convergence zone. The proposed flight path intercepted two mature convective cells with echo-top heights greater than $10 \mathrm{~km}$. The tropopause was located above $16 \mathrm{~km}$ in altitude.

Simulated convection on 27 December 2014 initiates from a boundary near the land feature of Singapore with intense convective cores that weaken and dissipate by 1200 UTC. After $1200 \mathrm{UTC}$, a secondary boundary oriented along $5^{\circ} \mathrm{S}$ latitude propagates northward and initiates a convective line more than $100 \mathrm{~km}$ long over the Java Sea. Convection along the boundary has echo-top heights greater than 15 - and 2-km radar reflectivity values greater than $50 \mathrm{~dB} Z$, but dissipates by 2200 UTC. The particular convective feature that likely influenced the aircraft along its flight path is simulated at 0300 UTC 28 December, approximately $4 \mathrm{~h}$ after satellite observations indicated (Fig. 5). This simulated convection was linear, extending along $5^{\circ} \mathrm{S}$ and $4.5^{\circ} \mathrm{S}$ latitudes with echo-top heights above $14 \mathrm{~km}$. The simulated tropopause height on 27 December 2014 is $15.5 \mathrm{~km}$. The convective features of interest in this particular simulation are approximately $1^{\circ}$ too far south and slightly farther east than observed convection (Fig. 5). While a location bias is apparent in this case day, the organization of convection and convective type agrees with observations, giving confidence in accurately representing the convective environment. The time period of 0000-0400 UTC 28 December will be used to analyze the influence of convective stage on turbulence (section 4) as
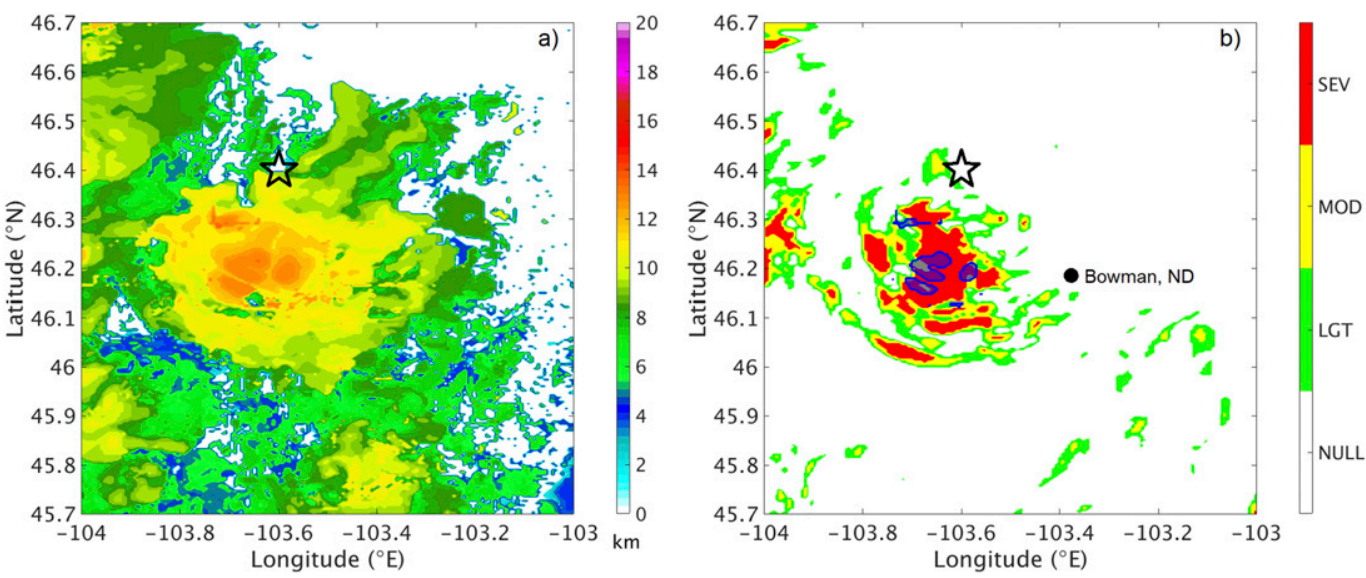

FIG. 10. (a) Simulated echo-top heights and (b) maximum second-order structure functions at 2210 UTC 10 Jul 1997 (C2) between 14 and $16 \mathrm{~km}$. Echo tops greater than $13 \mathrm{~km}$ are shown in (b) as blue contours (and shading) and the black star represents the location of the aircraft at 2141 UTC. 

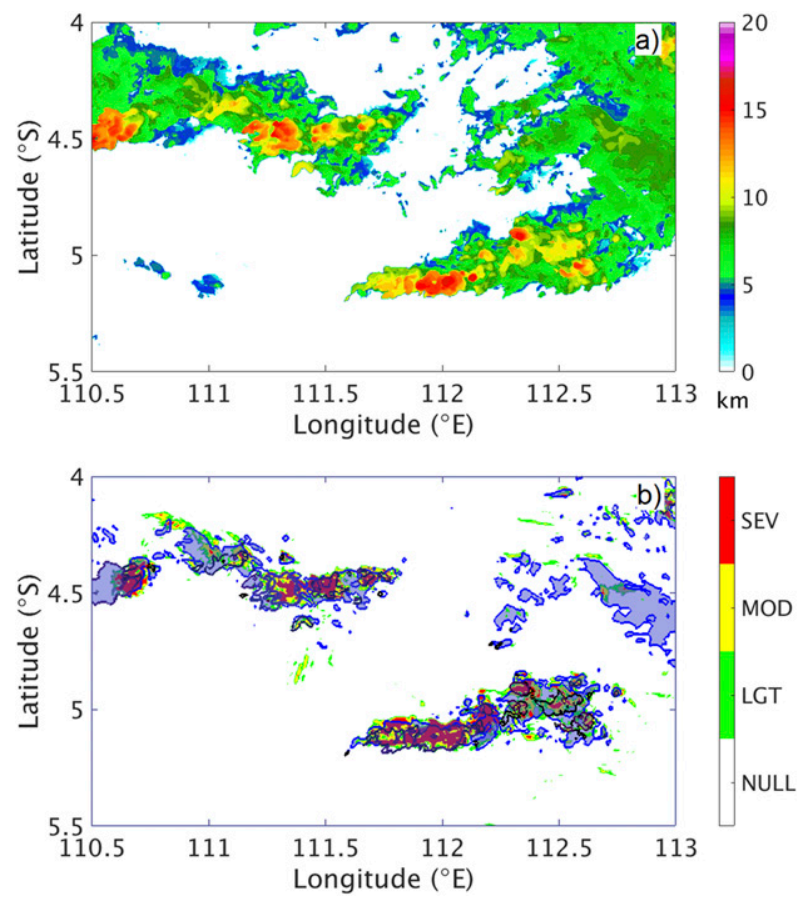

FIG. 11. (a) Simulated echo-top heights and (b) maximum second-order structure functions at 0300 UTC 28 Dec 2014 (C3) between 8 and $12 \mathrm{~km}$. Echo tops greater than 8 (10 and 12) $\mathrm{km}$ are shown in (b) as blue (black and dark purple) contours. Blue shading is used to represent the area of echo-top heights greater than $8 \mathrm{~km}$.

the simulated convection is oriented along the flight path with the vertical depths and areal coverage similar to observations.

SF are evaluated between 8 and $12 \mathrm{~km}$ (Fig. 11). Of interest is the areal coverage of out-of-cloud turbulence around the convection, as the aircraft was navigating around the observed convection. SF diagnose out-of-cloud turbulence within $30 \mathrm{~km}$ of active convection. The most intense turbulence is to the southeast and northwest of the western convective cell. The localized turbulence regions identified by SF are representative of observations as the aircraft navigated around the convection with and without encountering turbulence. SF would have been a beneficial diagnostic for this particular case near the convective boundaries.

\section{d. 4 June 2018 (C4)}

On 4 June 2018, near 0100 UTC an aircraft reported severe turbulence at $33.4^{\circ} \mathrm{N},-106.4^{\circ} \mathrm{E}$ while flying at $11 \mathrm{~km}$. Convection was forced by an upper level front extending from Colorado to New Mexico and was forecasted to be severe in intensity due to high CAPE (greater than $3000 \mathrm{~J} \mathrm{~kg}^{-1}$ ) and bulk shear. Numerous reports of tornadoes and hail occurred in New Mexico and Texas. Echo-top heights ranged from $10 \mathrm{~km}$ to over $16 \mathrm{~km}$ in the most intense cells and the tropopause on this day was above $12 \mathrm{~km}$.

Simulated convection on 3 June 2018 forms along the east side of the San Andres mountain range and propagates eastward as the diurnal heating intensifies in a region with CAPE greater than $1900 \mathrm{~J} \mathrm{~kg}^{-1}$. Simulated radar reflectivity values are greater than $55 \mathrm{~dB} Z$ during the initial phase. The convective line begins to form a bowing segment near 0100 UTC as it moves out of the domain. Echo-top heights exceed $12 \mathrm{~km}$ after 2200 UTC in four regions along a $200-\mathrm{km}$ convective line. Convection propagates across the region of interest approximately $2 \mathrm{~h}$ too early when compared to observations and with slightly lower echo tops than observed (Fig. 6). The simulated cells most representative of the observed convection occur near $2300 \mathrm{UTC}$ at $33.5^{\circ} \mathrm{N},-106.6^{\circ} \mathrm{E}$. The time period of 1900-2300 UTC 3 June will be used to analyze the influence of convective stage on turbulence (section 4) as the simulated convection resembles observed convection in location, strength, and morphology.

Simulated echo-top heights and SF are evaluated between 8 and $12 \mathrm{~km}$ (Fig. 12). The simulated storm depths in this case agree with radar observations in the strength and location. SF identify moderate or greater turbulence in the convective cloud and localized regions of moderate or greater out of cloud. Near the location of the aircraft there is a strong gradient in turbulence intensity, but out of convective cloud the turbulence is light. In-cloud turbulence intensity was well represented by SF and likely underestimated out of cloud.

\section{e. 20 June 2017 (C5)}

On 20 June 2017, a Boeing 737 encountered severe turbulence at $11 \mathrm{~km}$ in altitude while flying over the Gulf of Mexico $\left(21.84^{\circ} \mathrm{N},-86.16^{\circ} \mathrm{E}\right)$ near 1651 UTC. Convection was present along the flight route as the aircraft traveled from Panama City, Panama to Houston, TX. Additional information regarding the synoptic conditions for this particular case can be found in Barber et al. (2019). Convection was abundant in the flight region with storm depths exceeding $14 \mathrm{~km}$ in altitude. The tropopause on this day was above $14.3 \mathrm{~km}$ and CAPE was greater than $1500 \mathrm{~J} \mathrm{~kg}^{-1}$. Satellite observations and flight records indicate the plane was out of cloud at the time of the turbulence encounter, navigating between two regions of developing convection.

Simulated convection on 20 June 2017 initiates from the forcing of a seabreeze north of the Yucatan Peninsula at 1000 UTC as a narrow convective line with $2-\mathrm{km}$ radar reflectivity values greater than $45 \mathrm{~dB} Z$. Simulated convection intensifies and then persists between $-87^{\circ}$ and $-86^{\circ} \mathrm{E}$ through 1800 UTC. The simulated environment was favorable for intense convection with CAPE values greater than $2500 \mathrm{~J} \mathrm{~kg}^{-1}$. Echo-top heights exceeded $13 \mathrm{~km}$ after 1240 UTC along the convective line and reached $17 \mathrm{~km}$ in numerous cells. Simulated convective depth was slightly higher than observations and simulated convection extends much farther north (Fig. 7). However, the horizontal width of the simulated convective line and observed convective line are very similar (approximately $0.5^{\circ}$ in longitude). Interestingly, the second prominent convective feature east of $-86^{\circ} \mathrm{E}$ is not simulated in the 500-m domain. However, the aircraft at the time of the turbulence encounter was closer to the western line and therefore is more important to accurately represent the 

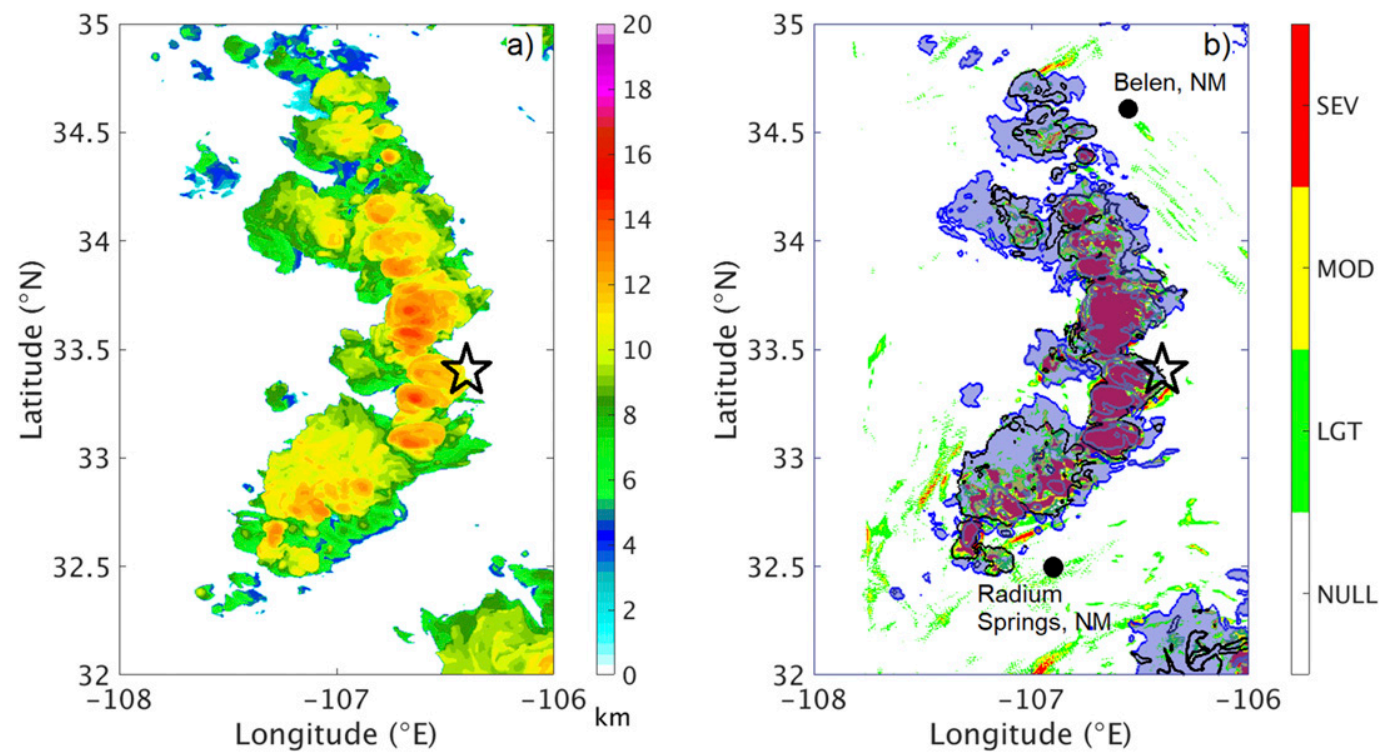

FIG. 12. (a) Simulated echo top-heights and (b) maximum second-order structure functions at 2300 UTC 3 Jun 2018 (C4) between 8 and $12 \mathrm{~km}$. Echo tops greater than 8 (10 and 12) km are shown in (b) as blue (black and dark purple) contours. Blue shading is used to represent the area of echo-top heights greater than $8 \mathrm{~km}$. The black star represents the location of the aircraft at 0108 UTC 4 Jun.

western line. The time period of 1200-1800 UTC 20 June will be used to analyze the influence of convective stage on turbulence probability (section 4 ).

Simulated echo-top heights and SF at 1650 UTC are shown in Fig. 13. SF indicate moderate or greater turbulence in cloud along the convective line and light to moderate or greater turbulence along the cloud boundaries. Approximately $50 \mathrm{~km}$ to the east and west of the convective line, a broad area of increased turbulence severity is present. Near the location of the aircraft, turbulence was identified as light with large gradients in turbulence intensity. SF accurately represented in- cloud turbulence intensity but likely under predicted out-ofcloud areal coverage.

\section{f. 29 June 2018 (C6)}

On 29 June 2018, at 2257 UTC an Airbus A320 experienced severe turbulence while flying at an altitude of $11 \mathrm{~km}$ near Dickinson, ND $\left(46.51^{\circ} \mathrm{N},-102.46^{\circ} \mathrm{E}\right)$. The aircraft descended more than $600 \mathrm{~m}$ and decreased in speed by $50 \mathrm{kt}(1 \mathrm{kt} \approx$ $0.51 \mathrm{~m} \mathrm{~s}^{-1}$ ) at the time of the encounter. Convection was present along the flight path, with composite radar reflectivity values exceeding $45 \mathrm{dBZ}$ in isolated cells west of Bismarck,
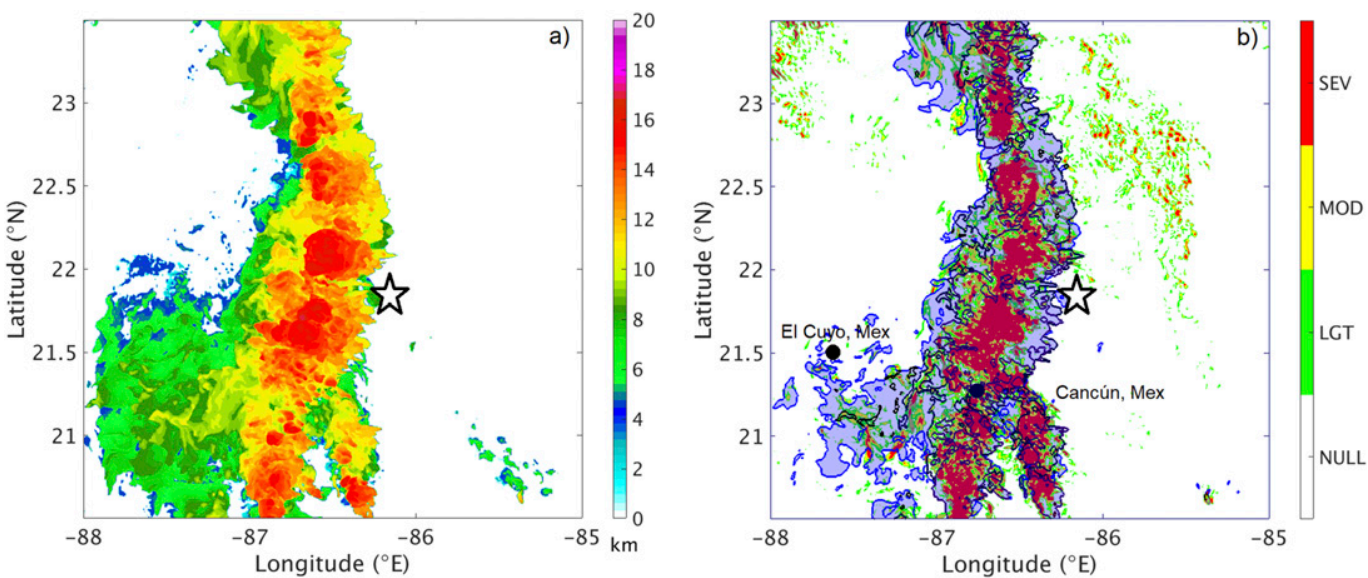

FIG. 13. (a) Echo-top heights and (b) maximum second-order structure functions at 1650 UTC 20 Jun 2017 (C5) between 8 and $12 \mathrm{~km}$. Echo tops greater than 8 (10 and 12) $\mathrm{km}$ are shown in (b) as blue (black and dark purple) contours. Blue shading is used to represent the area of echo-top heights greater than $8 \mathrm{~km}$. The black star represents the location of the aircraft at 1651 UTC. 

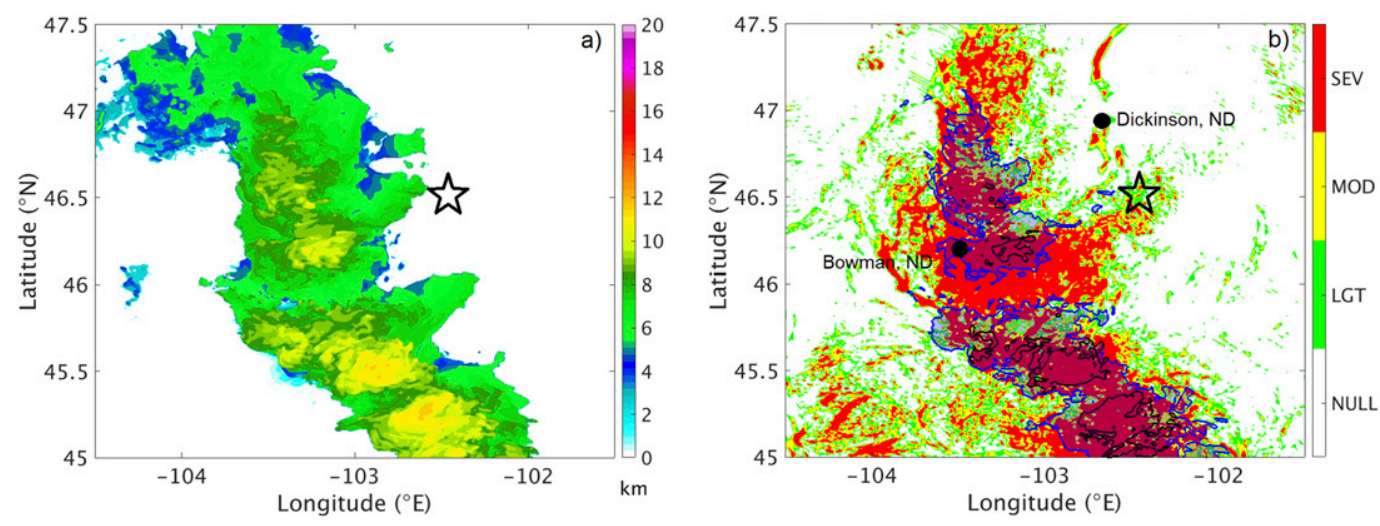

FIG. 14. (a) Echo-top heights and (b) maximum second-order structure functions at 2250 UTC 29 Jun 2018 (C6) between 8 and $12 \mathrm{~km}$. Echo tops greater than 8 (10 and 12) km are shown in (b) as blue (black and dark purple) contours. Blue shading is used to represent the area of echo-top heights greater than $8 \mathrm{~km}$. The black star represents the location of the aircraft at 2257 UTC.

North Dakota, and more intense cells exceeding radar reflectivity values of $55 \mathrm{dBZ}$ in northwest South Dakota. It is important to note that the flight path was along a region of Montana, North Dakota, and South Dakota where there is a void in radar coverage. Convection was severe in western South Dakota where numerous storm reports were recorded including tornadoes, large hail, and severe winds within the hour of the turbulence encounter. CAPE exceeded $3000 \mathrm{~J} \mathrm{~kg}^{-1}$ and echo-top heights were greater than $14.7 \mathrm{~km}$.

Simulated convection at 1900 UTC 29 June 2018 initiates near the western South Dakota-North Dakota border. Isolated cells intensify in two distinct regions with simulated $2-\mathrm{km}$ radar reflectivity values greater than $50 \mathrm{dBZ}$. The cells propagate eastward and weaken by 0000 UTC 30 June (Fig. 8). The strongest observed and simulated convection near 2300 UTC is to the southwest of Lemmon, South Dakota. A simulated and observed cell is also weakening southwest of Dickinson, South Dakota, near 2300 UTC. Echo-top heights exceed $10 \mathrm{~km}$ throughout the period of interest with the deepest storms to the south. The time period of 1800-0000 UTC 29-30 June will be used to analyze the influence of convective stage on turbulence probability (section 4).

Simulated echo-top heights and SF at 2250 UTC are shown in Fig. 14. SF diagnose a large region of moderate or greater turbulence both in cloud and out of cloud near convection. Near the location of the aircraft, there is a localized area of enhanced turbulence out of cloud. SF would have been a beneficial diagnostic for this convective day to identify turbulence in cloud and out of cloud.

\section{Impacts of convective stage}

Figure 15 provides the distribution of out-of-cloud turbulence for each case day for grid points closest to mature convective objects and grid points closest to developing convective objects between 8 and $12 \mathrm{~km}$. Near mature convection (Fig. 15a), the midlatitudes (solid lines) have a higher probability of turbulence than the tropics (dashed lines). But the probability of strong turbulence is greater for both tropical and midlatitude cases near developing convective objects
(Fig. 15b) by nearly an order of magnitude when compared to probabilities near mature convective objects (with the exception of $\mathrm{C} 1$ ). This finding highlights the hazards associated with developing convection in regards to aviation operations. The greatest increase in turbulence probability from the mature subset to the developing subset occurs for the midlatitude cases. While the developing convection signal shown here is weaker for the tropics, the methodology of computing out-ofcloud turbulence is possibly overly conservative for regions close to convection, which has a stronger impact on tropical results (i.e., must be at least $7 \Delta x$ or $3.5 \mathrm{~km}$ away from a cloudy grid point).

\section{Characteristics of the environment near convection}

In this section, comparisons of the simulated environment around mature and developing convection for the six cases will be made and related to the likelihood of turbulence. Mean outof-cloud static stability and vertical wind shear are examined between 8 and $12 \mathrm{~km}$ (representing the typical cruising altitudes for commercial aircraft) for all grid points closest to mature convective objects and all grid points closest to developing convective objects, at a frequency of $10 \mathrm{~min}$ during the periods shown in Table 1. The objective of this analysis is to determine if the average near-storm environmental conditions near various convective types in the midlatitudes and tropics are similar. Specifically, are the midlatitude and tropical static stability and vertical wind shear distributions the same during similar convective periods, and is the turbulence response the same? Additionally, near-storm environmental conditions are analyzed for both developing and mature convective stages. Importantly, a given storm environment will vary depending on both the background environment and influence of the storm on that environment, and this environment can vary on meso- to microscales; this study does not differentiate between these two factors. Instead, we are investigating the variability in environmental (near-storm and background) factors in different regions and storm stages and how that might relate to turbulence production. Note, median, minimum, 

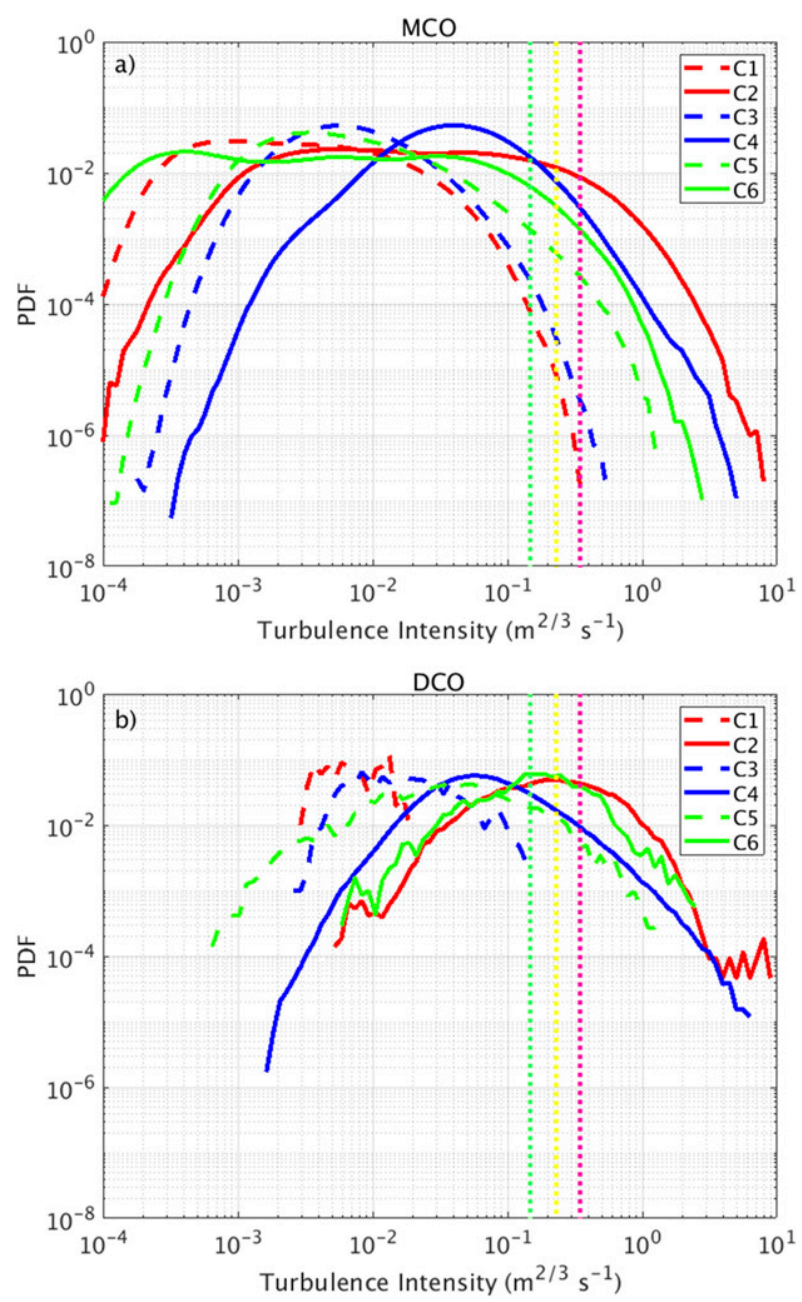

FIG. 15. Distribution of out-of-cloud turbulence diagnosed by second-order structure functions $\left(\mathrm{m}^{2 / 3} \mathrm{~s}^{-1}\right)$ between 8 and $12 \mathrm{~km}$ nearest to (a) mature convection (MCO) and (b) developing convection (DCO) for the six simulations. Dashed lines are tropical cases and solid lines are midlatitude cases. The green (yellow and magenta) vertical line represents the threshold for light (moderate and severe) turbulence; see Table 3 for threshold values.

and maximum static stability and vertical wind shear values are also provided in Tables 5 and 6 to illustrate the statistical variability of the environment.

The distributions of mean static stability $\left(N^{2}\right)$ for the six cases are shown in Fig. 16. Near mature convective objects (Fig. 16a), the mean static stability is lower for the tropical cases than the midlatitude cases (Table 5), which is expected (Saha and Singh 1972; Garstang and Fitzjarrald 1999; Frierson 2006; Frierson and Davis 2011). Near developing convection (Fig. 16b), again the tropical cases have a lower mean static stability than the midlatitude cases, and subtle variation between the cases themselves. Interestingly, the midlatitude distributions are more similar near developing convection (Fig. 16b, solid lines) than mature convection (Fig. 16a, solid lines), suggesting that static stability is not influenced by storm type during the developing stage. Importantly, for five of the six cases, static stability is lower (by $0.2 \times 10^{-5} \mathrm{~s}^{-2}$ in the tropics and by $0.2 \times 10^{-4} \mathrm{~s}^{-2}$ in the midlatitudes) near developing convection compared to mature convection (Table 5). These results indicate that environmental stability processes influence turbulence in the midlatitudes and tropics near developing convection more than during the mature stage.

The out-of-cloud vertical shear $\left(S_{v}^{2}\right)$ distributions between 8 and $12 \mathrm{~km}$ (Fig. 16c) near mature convection have large variability (in breadth and mean and median values) between the six cases, likely as a result of convective type. The largest mean vertical wind shear is associated with the midlatitude cases (Table 6), which again is expected when nominal vertical wind shear values are compared to the tropics (Wissmeier and Goler 2009). The breadth of vertical wind shear is also the greatest for the midlatitudes. Near developing convection (Fig. 16d), $S_{v}^{2}$ distributions shift toward higher shear values for all six of the cases (Table 6). In the tropics, during the developing stage (Fig. 16d) the distributions of $S_{v}^{2}$ vary significantly by storm type. On the other hand, in the midlatitudes near developing convection (Fig. 16c), the extreme $S_{v}^{2}$ values for C2 and C4 are very similar to one another (less influenced by storm type). The larger $S_{v}^{2}$ near developing convection is hypothesized to be caused by deformation at the cloud boundary and increases the probability of turbulence through shear producing mechanisms.

\section{Distributions of environment variables subset by turbulence intensity}

The distributions of $N^{2}$ and $S_{v}^{2}$ are subset by turbulence intensity (i.e., turbulence that is light only or turbulence that is moderate or greater only) to discern if turbulence intensity is influenced by the environment (Fig. 17, note that only the environment near mature convection is shown). Specifically, is the environment (near-storm and background) significantly different for all cases where there is only light (LGT) turbulence and only moderate or greater (MOG) turbulence? When $N^{2}$ is examined as a subset of turbulence intensity, $N^{2}$ in the midlatitudes is very similar for LGT and MOG turbulence (Fig. 17a). The turbulence intensity of the tropical cases is also not dependent on static stability (Fig. 17b). These results are consistent for developing convection (not shown). In relationship to aviation operations, the environmental $N^{2}$ in the tropics and midlatitudes is not significantly different for MOG turbulence versus LGT turbulence near convective objects. These results suggest that $N^{2}$ distributions would not provide enough information to discern between the likelihood of no turbulence (NULL) or LGT or MOG turbulence.

The distributions of $S_{v}^{2}$ between the 8 - and $12-\mathrm{km}$ subset by turbulence intensity for the midlatitude cases are shifted toward higher $S_{v}^{2}$ values, indicating that turbulence with greater intensity is occurring more frequently in regions of increased shear (Fig. 17c). The mean $S_{v}^{2}$ for the midlatitude cases (Fig. 17c) has increased by nearly half an order of magnitude from the LGT turbulence to the MOG turbulence. In the tropics $S_{v}^{2}$ slightly increases for MOG turbulence for C3 and C5 (Fig. 17d). In relationship to aviation operations, the environmental $S_{v}^{2}$ in the midlatitudes is significantly different for 

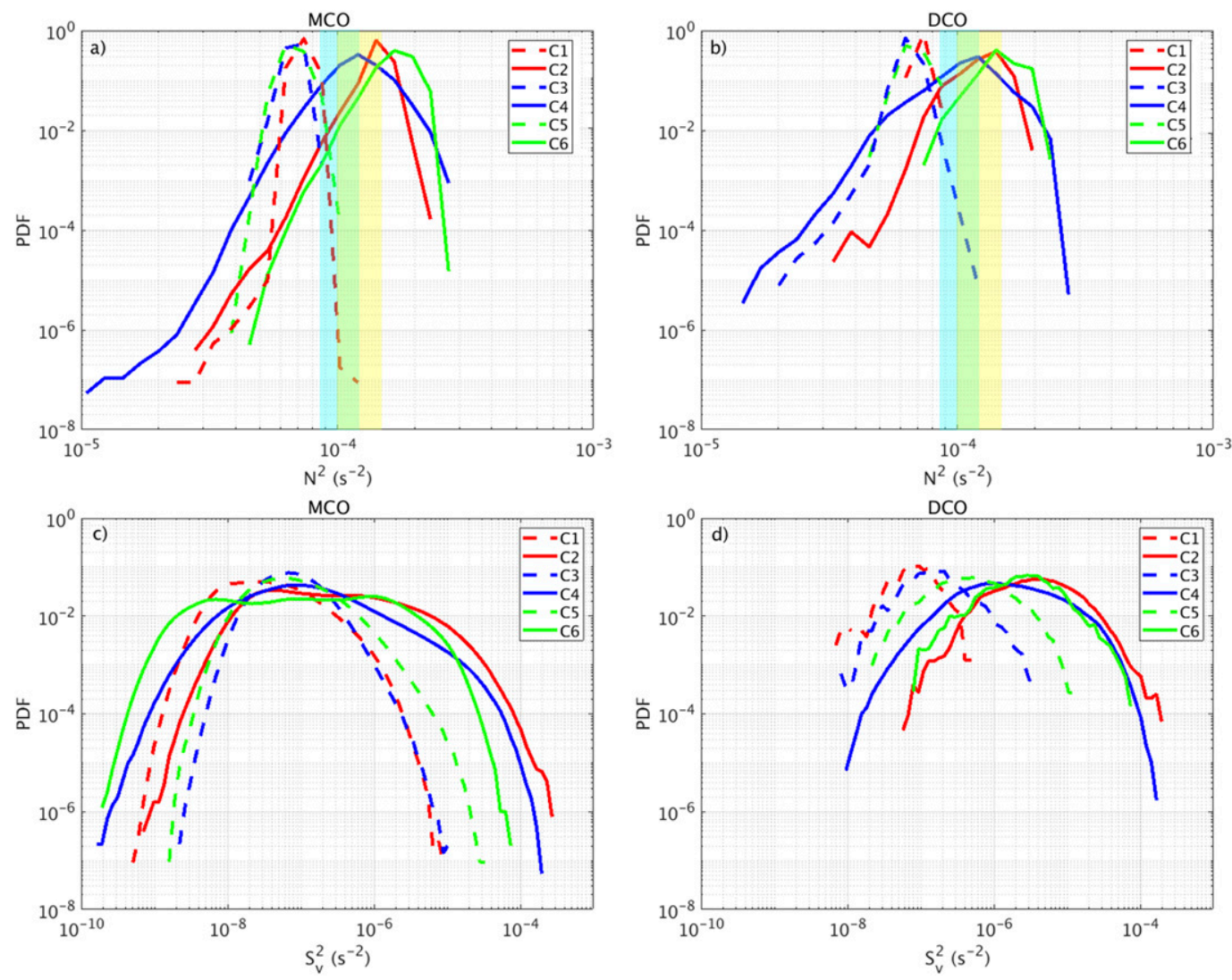

FIG. 16. (a),(b) Distribution of mean out-of-cloud static stability $\left(\mathrm{s}^{-2}\right)$ and (c),(d) mean vertical wind shear $\left(\mathrm{s}^{-2}\right)$ between 8 and $12 \mathrm{~km}$ nearest to (a),(c) mature convection (MCO) and (b),(d) developing convection (DCO) for the six simulations. Dashed lines are tropical cases and solid lines are midlatitude cases. Typical ranges of static stability are shaded (cyan: tropics; pale yellow: midlatitudes).

turbulent regions than null regions near convection. The shift toward higher values of $S_{v}^{2}$ could be an indicator of increased turbulence potential. The distinction in distributions between the mature convective environment and the developing convective environment (not shown) look similar, meaning the same shift in distribution could be used for turbulence prediction near mature and developing convection. Because at least some of the shear magnitude is likely due to storm outflow, an additional investigation to determine the probability of turbulence specifically near convective outflow regions with respect to storm stage would be of considerable value (future work).

Correlations between $N^{2}$ and $S_{v}^{2}$ and turbulence intensity are examined to determine if turbulence intensity can be estimated by the parameters near convection (Figs. 18 and 19). Figure 18 shows the correlation of $N^{2}$ and turbulence for all cases subset by mature and developing convection. For the tropical cases (Figs. 18b,d,f), there is no correlation between $N^{2}$ and turbulence intensity for the environment near mature or developing convection. For the midlatitude cases C2 and C6 (Figs. 18a,e), there is a weak negative correlation between $N^{2}$ and turbulence intensity for developing and mature convection (stronger correlation for developing convection). Figure 19 shows the correlation of $S_{v}^{2}$ and turbulence intensity for all cases subset by mature and developing convection. For all six cases there is a weak positive correlation between $S_{v}^{2}$ and turbulence intensity. The correlations are generally slightly stronger for developing convection in the midlatitude cases (Figs. 19a,c,e). These results suggest that $S_{v}^{2}$ may be a promising variable to use to diagnose turbulence intensity potential in the midlatitudes. Overall, however, the correlations are not that impressive for both $N^{2}$ and $S_{v}^{2}$, motivating the need for more cases to build up robust statistics.

\section{Discussion and conclusions}

Convectively induced turbulence (CIT) is a forecasting challenge for aviation operations. Convective properties including storm height and environmental conditions such as stability and vertical wind shear can influence turbulence production significantly, all of which must be predicted correctly in model simulations to offer aviation operations assistance in turbulence avoidance. Past CIT research has focused on convection over the continental United States aiding in the creation of the Federal Aviation Administration Thunderstorm Avoidance guidelines. The lack of tropical CIT 

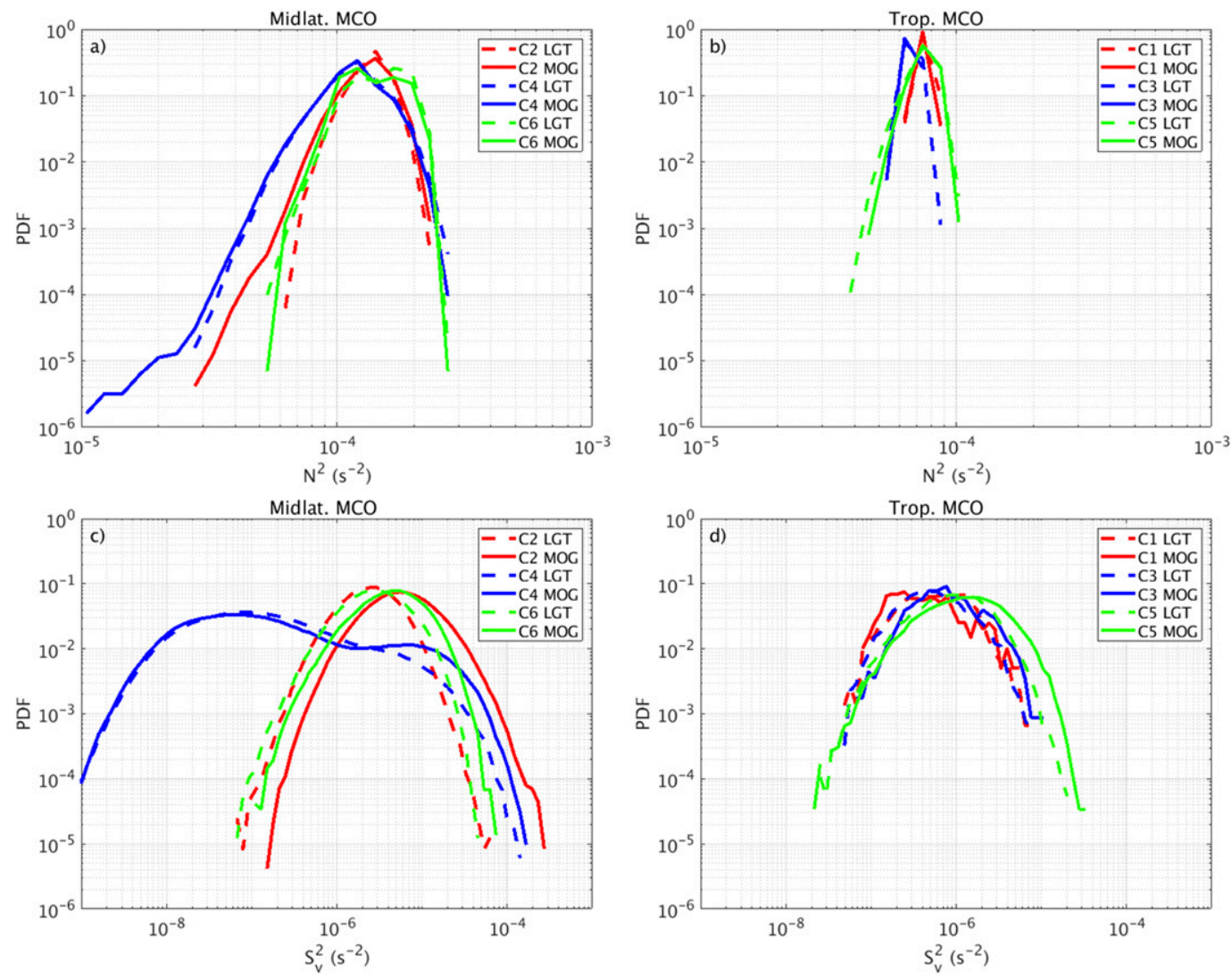

FIG. 17. (a),(b) Distribution of mean out-of-cloud static stability $\left(\mathrm{s}^{-2}\right)$ and (c),(d) mean vertical wind shear $\left(\mathrm{s}^{-2}\right)$ between 8 and $12 \mathrm{~km}$ nearest to mature convection (MCO) for the six simulations [(a) and (c) are midlatitude cases; (b) and (d) are tropical cases] subset by turbulence intensity (LGT: dashed lines; MOG: solid lines).

investigations limits the improvement of tropical CIT avoidance. Six cases of CIT were simulated at high vertical and horizontal resolution $(\Delta x, \Delta y=500 \mathrm{~m}, \Delta z \approx 350 \mathrm{~m})$. These simulations were used to investigate the variability of turbulence diagnosed by second-order structure functions in tropical and midlatitude regions, in order to determine the variability in diagnostics when implemented globally. In addition, these simulations were used to determine if the convective environment, defined as the out of cloud area within $30 \mathrm{~km}$ of convection, varies for storm stage and region (tropical and midlatitude), and if the variation in convective environment influences turbulence intensity. Simulated convection compared well to observational datasets from ground-based radar and satellite in morphology and strength for the majority of the cases, while timing for the tropical simulations generally had a lag of up to $4 \mathrm{~h}$.

Turbulence intensity and probability were examined for the six cases and subset by convective stage (mature or developing) by tracking convective objects in 10-min intervals. The probability of turbulence near convection was found to vary significantly by region and convective stage. Turbulence probability was found to be greatest in the midlatitudes and increased near developing convection. Turbulence probability in the tropics varied by convective stage and also increased near developing convection (Fig. 15). The increased probability of turbulence near developing convection in the midlatitudes and the tropics is of concern for aviation operations because generally pilots avoid flying near mature convection (especially when following the turbulence avoidance guidelines) and presumably will fly closer to developing convection. In addition, there are limited real-time observational datasets available to pilots in tropical regions to aid in flight diversions.

Static stability and vertical wind shear were used to characterize the out of cloud convective environment for the six simulations in this study. The environmental conditions out of cloud near convection in the midlatitudes and tropics varied significantly as was expected. Static stability was less for the tropical environment on average than in the midlatitudes and was greater around mature convection than developing convection, but was not found to directly influence turbulence potential. Vertical wind shear was less for the tropical environment than in the midlatitudes and increased around developing convection in both the midlatitudes and tropics. When turbulence was subset by intensity, static stability was not significantly different. However, average vertical wind shear increased for turbulent locations with MOG turbulence intensity in the midlatitudes. In terms of turbulence prediction, 

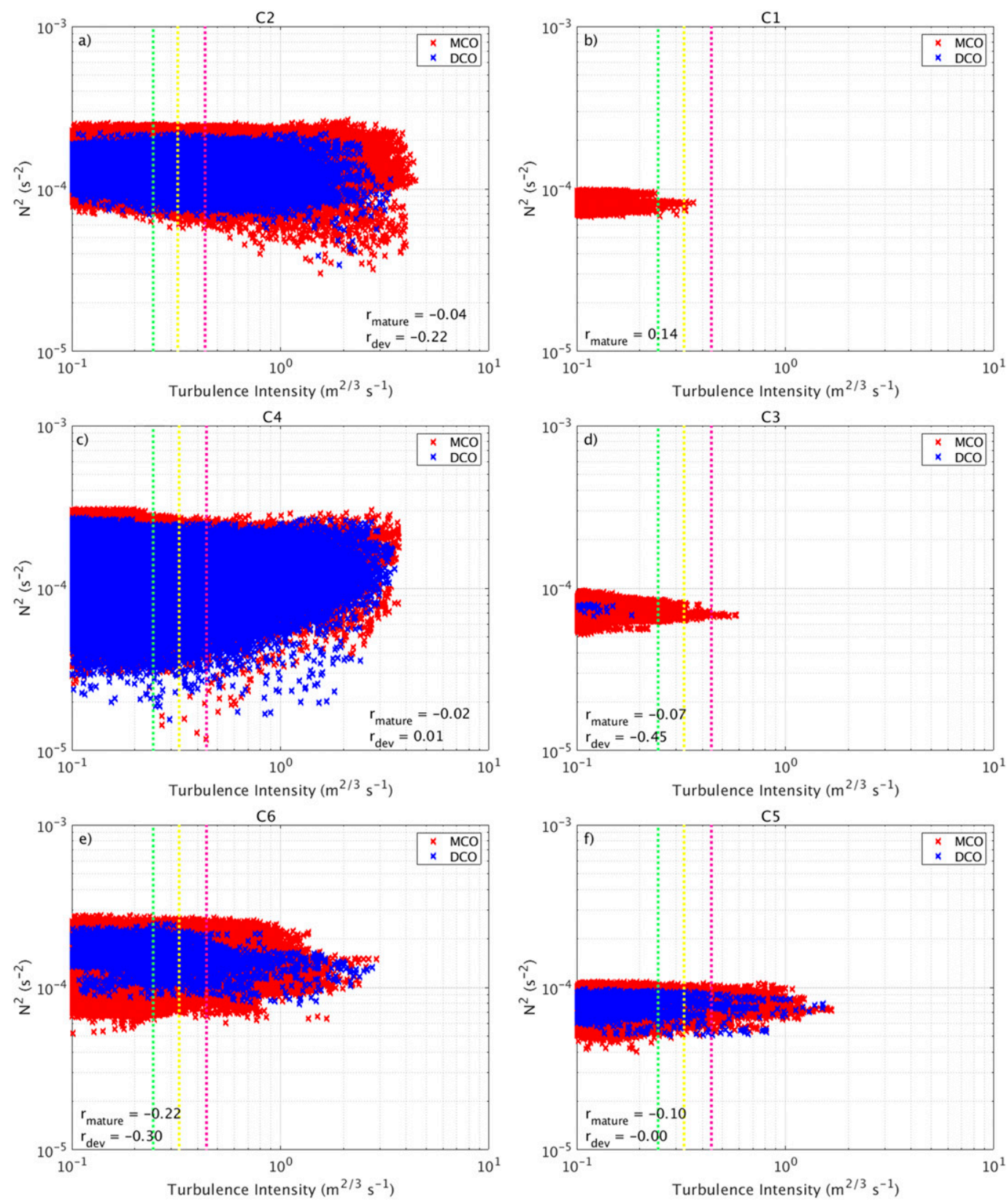

FIG. 18. Correlation of mean out-of-cloud static stability $\left(\mathrm{s}^{-2}\right)$ and turbulence intensity between 8 and $12 \mathrm{~km}$ nearest to mature convection (MCO; red) and developing convection (DCO; blue) for the six simulations: (a),(c),(e) midlatitude cases and (b),(d),(f) tropical cases. The correlation coefficients for the data subset by convective object type are provided $\left(r_{\text {mature }}\right.$ and $\left.r_{\text {dev }}\right)$.

increased vertical wind shear could be indicative of increased turbulence intensity especially near developing convection.

Aviation operations in the United States currently do not have federally mandated thunderstorm avoidance guidelines that are region or convective stage specific. The overall objective of this study was to determine if region-specific and convective stage specific guidelines are needed to decrease the probability of an aviation turbulence encounter. This study found that turbulence intensity only subtly varies by region (with greater probability near mature midlatitude convection), and therefore guidelines that are not region specific are adequate for midlatitudes and tropical turbulence avoidance. However, as was found for a single case in Barber et al. (2019), storm stage does have an important impact on turbulence potential, with proximity to developing convection increasing the turbulence probability for all intensities. When convection is subset by stage, regionality does cause a substantial difference in turbulence potential. In the midlatitudes and tropics, 

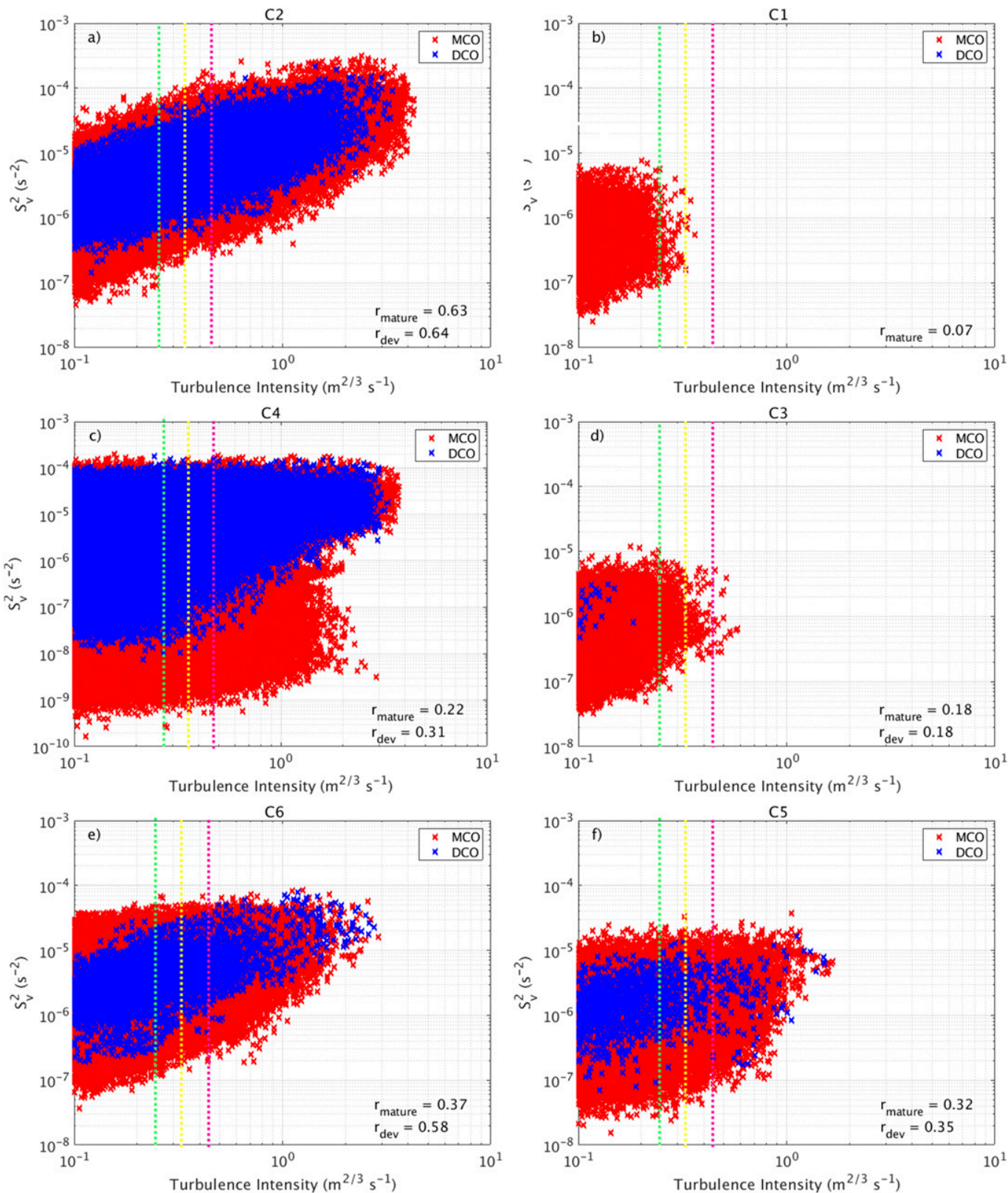

FIG. 19. Correlation of mean out-of-cloud vertical wind shear $\left(\mathrm{s}^{-2}\right)$ and turbulence intensity between 8 and $12 \mathrm{~km}$ nearest to mature convection (MCO-red) and developing convection (DCO-blue) for the six simulations: (a),(c),(e) midlatitude cases and (b),(d),(f) tropical cases. The correlation coefficients for the data subset by convective object type are provided $\left(r_{\text {mature }}\right.$ and $\left.r_{\mathrm{dev}}\right)$.

turbulence probability can increase by more than one order of magnitude near developing convection. The increase could be due to the increase in shear around the developing convection. With smaller background shear levels in the tropics, the local impacts on shear may be more important for turbulence production. This study found important differences in turbulence potential in the six cases and motivates the need for more simulations of CIT at high resolution to understand turbulence mechanisms in both tropical and midlatitude regions. More research will further increase understanding of CIT on aviation operations and eventually lead to needed adaptations to the current avoidance guidelines.

Acknowledgments. A thank you is extended to the three anonymous reviewers whose comments and suggestions helped elevate this manuscript. We thank Nikki Carson for her very careful review of this manuscript. The authors thank the Blue Waters Fellowship for its support of this research. Specifically, Tom Cortese at NCSA for his assistance with Blue Waters, as well as Scott Lathrop, and the entire Blue Waters 
Fellowship team. This research is part of the Blue Waters sustained-petascale computing project, which is supported by the National Science Foundation (Awards OCI-0725070 and ACI-1238993) and the State of Illinois. Blue Waters is a joint effort of the University of Illinois at Urbana-Champaign and its National Center for Supercomputing Applications. This study is supported in part by the U.S. Department of Energy Office of Science Biological and Environmental Research as part of the Atmospheric System Research (ASR) Program. Pacific Northwest National Laboratory is operated by Battelle for the U.S. Department of Energy under Contract DE-AC0576 RLO1830.

\section{REFERENCES}

Ahmad, N. N., and F. H. Proctor, 2011: Large eddy simulations of severe convection induced turbulence. NASA Tech. Rep. AIAA 3201, 42 pp.

Barber, K. A., 2015: Simulations of convectively-induced turbulence based on radar-based climatology of tropical storm types. M.S. thesis, Dept. of Atmospheric Sciences, University of North Dakota, 169 pp.

- 2019: Characteristics of convectively induced turbulence determined from tropical and midlatitude simulations. Ph.D. thesis, University of North Dakota, 234 pp.

— , G. L. Mullendore, and M. J. Alexander, 2018: Out-of-cloud convective turbulence: Estimation method and impacts of model resolution. J. Appl. Meteor. Climatol., 57, 121-136, https://doi.org/10.1175/JAMC-D-17-0174.1.

—, W. Deierling, G. L. Mullendore, C. Kessinger, R. Sharman, and D. M. Esparza, 2019: Properties of convectively induced turbulence over developing convection. Mon. Wea. Rev., 147, 3429-3444, https://doi.org/10.1175/MWR-D-18-0409.1.

Chin, H. S., M. M. Bradley, Q. Fu, and C. R. Molenkamp, 1995: Modeling of a tropical squall line in two dimensions: Sensitivity to radiation and comparison with a midlatitude case. J. Atmos. Sci., 52, 3172-3193, https://doi.org/10.1175/ 1520-0469(1995)052<3172:MOATSL>2.0.CO;2.

Dudhia, J., 1989: Numerical study of convection observed during the Winter Monsoon Experiment using a mesoscale twodimensional model. J. Atmos. Sci., 46, 3077-3107, https:// doi.org/10.1175/1520-0469(1989)046<3077:NSOCOD>2.0.CO;2.

Ellrod, G. P., and D. I. Knapp, 1992: An objective clear-air turbulence forecasting technique: Verification and operational use. Wea. Forecasting, 7, 150-165, https://doi.org/10.1175/ 1520-0434(1992)007<0150:AOCATF>2.0.CO;2.

FAA, 2017: Aeronautical information manual. Official Guide to Basic Flight Information and ATC Procedures, FAA, 435-539.

Frehlich, R., and R. Sharman, 2004a: Estimates of turbulence from numerical weather prediction model output with applications to turbulence diagnosis and data assimilation. Mon. Wea. Rev., 132, 2308-2324, https://doi.org/10.1175/1520-0493(2004) $132<2308$ :EOTFNW $>2.0 . \mathrm{CO} ; 2$.

$\longrightarrow$, and — 2004b: Estimates of upper level turbulence based on second order structure functions derived from numerical weather prediction model output. Preprints, 11th Conf. on Aviation, Range, and Aerospace Meteorology, Hyannis, MA, Amer. Meteor. Soc., 4.13, https://ams.confex.com/ams/ 11 aram22sls/techprogram/paper_81831.htm.

, and - 2010: Climatology of velocity and temperature turbulence statistics determined from rawinsonde and ACARS/AMDAR data. J. Appl. Meteor. Climatol., 49, 1149-1169, https://doi.org/10.1175/2010JAMC2196.1.
Frierson, D. M. W., 2006: Robust increases in midlatitude static stability in simulations of global warming. Geophys. Res. Lett., 33, L24816, https://doi.org/10.1029/2006GL027504.

_ , and N. A. Davis, 2011: The seasonal cycle of midlatitude static stability over land and ocean in global reanalyses. Geophys. Res. Lett., 38, L13803, https://doi.org/10.1029/2011GL047747.

Garstang, M., and D. R. Fitzjarrald, Eds., 1999: Introduction. Observations of Surface to Atmosphere Interactions in the Tropics, Oxford University Press, 3-48.

Hamada, A., and Y. N. Takayabu, 2016: Convective cloud top vertical velocity estimated from geostationary satellite rapidscan measurements. Geophys. Res. Lett., 43, 5435-5441, https://doi.org/10.1002/2016GL068962.

Janjić, Z. I., 1994: The step-mountain Eta coordinate model: Further developments of the convection, viscous sublayer, and turbulence closure schemes. Mon. Wea. Rev., 122, 927-945, https://doi.org/10.1175/1520-0493(1994)122<0927: TSMECM $>2.0 . \mathrm{CO} ; 2$.

- 1996: The surface layer in the NCEP Eta model. Preprints, 11th Conf. on Numerical Weather Prediction, Norfolk, VA, Amer. Meteor. Soc, 333-334.

, 2002: Nonsingular implementation of the Mellor-Yamada Level 2.5 scheme in the NCEP Meso model. NCEP Office Note 437, 61 pp., https://www.emc.ncep.noaa.gov/officenotes/ newernotes/on437.pdf.

Katzwinkel, J., H. Siebert, T. Heus, and R. A. Shaw, 2014: Measurements of turbulent mixing and subsiding shells in trade wind cumuli. J. Atmos. Sci., 71, 2810-2822, https:// doi.org/10.1175/JAS-D-13-0222.1.

Kessinger, C. J., 2017: An update on the convective diagnosis oceanic algorithm. 18th Conf. of Aviation, Range, and Aerospace Meteorology, Seattle, WA, Amer. Meteor. Soc., 211, https:// ams.confex.com/ams/97Annual/webprogram/Paper314031.html.

, and Coauthors, 2008: Convection diagnosis and nowcasting for oceanic aviation applications. Proc. SPIE, 7088, 708808, https://doi.org/10.1117/12.795495.

Kim, J.-H., and H.-Y. Chun, 2012: A numerical simulation of convectively induced turbulence above deep convection. J. Appl. Meteor. Climatol., 51, 1180-1200, https://doi.org/ 10.1175/JAMC-D-11-0140.1.

KNKT, 2015: Aircraft accident investigation report. Final Rep. 14.12.29.04, $206 \mathrm{pp}$.

Knox, J. A., D. W. McCann, and P. D. Williams, 2008: Application of the Lighthill-Ford theory of spontaneous imbalance to clear-air turbulence forecasting. J. Atmos. Sci., 65, 3292-3304, https://doi.org/10.1175/2008JAS2477.1.

Kolmogorov, A. N., 1941: The local structure of turbulence in incompressible viscous fluid at high Reynolds number. Dokl. Akad. Nauk SSSR, 30, 299-303.

Lane, T. P., and R. D. Sharman, 2008: Some influences of background flow conditions on the generation of turbulence due to gravity wave breaking above deep convection. J. Appl. Meteor. Climatol., 47, 2777-2796, https://doi.org/10.1175/2008JAMC1787.1.

, — - T. L. Clark, and H. M. Hsu, 2003: An investigation of turbulence generation mechanisms above deep convection. J. Atmos. Sci., 60, 1297-1321, https://doi.org/10.1175/15200469(2003)60<1297:AIOTGM>2.0.CO;2.

,-- S. B. Trier, R. G. Fovell, and J. K. Williams, 2012: Recent advances in the understanding of near-cloud turbulence. Bull. Amer. Meteor. Soc., 93, 499-515, https://doi.org/ 10.1175/BAMS-D-11-00062.1.

Lester, P. F., 1994: Turbulence: A New Perspective for Pilots. 1st ed. Jeppesen-Sanderson, 212 pp. 
Lim, K.-S. S., and S.-Y. Hong, 2010: Development of an effective double-moment cloud microphysics scheme with prognostic cloud condensation nuclei $(\mathrm{CCN})$ for weather and climate models. Mon. Wea. Rev., 138, 1587-1612, https://doi.org/ 10.1175/2009MWR2968.1.

Liu, C., and E. J. Zipser, 2005: Global distribution of convection penetrating the tropical tropopause. J. Geophys. Res., 110, D23104, https://doi.org/10.1029/2005JD006063.

May, P. T., and D. K. Rajopadhyaya, 1999: Vertical velocity characteristics of deep convection over Darwin, Australia. Mon. Wea. Rev., 127, 1056-1071, https://doi.org/10.1175/15200493(1999)127<1056:VVCODC>2.0.CO;2.

Mlawer, E., J. Steven, J. Taubman, P. D. Brown, M. J. Iacono, and S. A. Clough, 1997: Radiative transfer for inhomogeneous atmospheres: RRTM, a validated correlated-k model for longwave. J. Geophys. Res., 102, 16 663-16 682, https://doi.org/ 10.1029/97JD00237.

Monette, S. A., and J. M. Sieglaff, 2014: Probability of convectively induced turbulence associated with geostationary satelliteinferred cloud-top cooling. J. Appl. Meteor. Climatol., 53, 429436, https://doi.org/10.1175/JAMC-D-13-0174.1.

Monin, A. S., and A. M. Obukhov, 1954: Basic laws of turbulent mixing in the surface layer of the atmosphere. Contrib. Geophys. Inst. Acad. Sci. USSR, 151, 163-187.

Morrison, H. G., G. Thompson, and V. Tatarskii, 2009: Impact of cloud microphysics on the development of trailing stratiform precipitation in a simulated squall line: Comparison of oneand two-moment schemes. Mon. Wea. Rev., 137, 991-1007, https://doi.org/10.1175/2008MWR2556.1.

Muñoz-Esparza, D., R. Sharman, J. Sauer, and B. Kosović, 2018: Toward low-level turbulence forcasting at eddy-resolving scales. Geophys. Res. Lett., 45, 8655-8664, https://doi.org/ 10.1029/2018GL078642.

NTSB, 1997: Accident Rep. FTW97IA261. The National Transportation Safety Board, 4 pp. [Available from NTSB, Public Inquiries Branch, 490 L'Enfant Plaza SW, Washington, DC 20594]

_- 2011: National Transportation Safety Board aviation incident data summary. Case summary 1, 3 pp., https://app. ntsb.gov/pdfgenerator/ReportGeneratorFile.ashx?EventID = 20090810X21314\&AKey $=1 \&$ RType $=$ Summary \&IType $=$ IA $/$.

Pearson, J. M., and R. D. Sharman, 2017: Prediction of energy dissipation rates for aviation turbulence. Part II: Nowcasting convective and nonconvective turbulence. J. Appl. Meteor. Climatol., 56, 339-351, https://doi.org/10.1175/JAMC-D-160312.1.

Saha, K. R., and S. S. Singh, 1972: On the distribution of mean static stability and mean Richardson number in the tropical atmosphere. J. Meteor. Soc. Japan, 109, 313-323.
Schumacher, C., S. Stevenson, and C. R. Williams, 2015: Vertical motions of the tropical convective cloud spectrum over Darwin, Australia. Quart. J. Roy. Meteor. Soc., 141, 22772288, https://doi.org/10.1002/qj.2520.

Sharman, R. D., and J. M. Pearson, 2017: Prediction of energy dissipation rates for aviation turbulence. Part I: Forecasting nonconvective turbulence. J. Appl. Meteor. Climatol., 56, 317337, https://doi.org/10.1175/JAMC-D-16-0205.1.

— C. C. Tebaldi, G. Wiener, and J. Wolff, 2006: An integrated approach to mid- and upper-level turbulence forecasting. Wea. Forecasting, 21, 268-287, https://doi.org/10.1175/WAF924.1.

Skamarock, W. C., 2004: Evaluating mesoscale NWP models using kinetic energy spectra. Mon. Wea. Rev., 132, 3019-3032, https://doi.org/10.1175/MWR2830.1.

_- and J. B. Klemp, 2008: A time-split nonhydrostatic atmospheric model for weather research and forecasting applications. J. Comput. Phys., 227, 3465-3485, https://doi.org/ 10.1016/j.jcp.2007.01.037.

Statista, 2020: Estimated annual growth rates for passenger air traffic from 2017 to 2036, by region. Accessed 12 January 2020, https://www.statista.com/statistics/269919/growth-rates-forpassenger-and-cargo-air-traffic/.

Tewari, M., and Coauthors, 2004: Implementation and verification of the unified Noah Land Surface model in the WRF model. Preprints, 20th Conf. on Weather Analysis and Forecasting/16th Conf. on Numerical Weather Prediction, Seattle, WA, Amer. Meteor. Soc, 14.2a, https://ams.confex.com/ ams/84Annual/techprogram/paper_69061.htm.

Vant-Hull, B., W. Rossow, and C. Pearl, 2016: Global comparisons of regional life cycle properties and motion of multiday convective systems: Tropical and midlatitude land and ocean. J. Climate, 29, 5837-5858, https://doi.org/10.1175/JCLI-D-150698.1.

Vasquez, T., 2009: Investigative meteorological report Continental Flight 128 turbulence near Dominican Republic. Meteorology Rep. 1, 9 pp., https://www.weathergraphics.com/tim/report coa128.pdf/.

Wissmeier, U., and R. Goler, 2009: A comparison of tropical and midlatitude thunderstorm evolution in response to wind shear. J. Atmos. Sci., 66, 2385-2401, https://doi.org/10.1175/ 2009JAS2963.1.

Yuter, S. E., R. A. Houze, A. Smith, T. T. Wilheit, and E. Zipser, 2005: Physical characterization of tropical oceanic convection observed in KWAJEX. J. Appl. Meteor., 44, 385-415, https:// doi.org/10.1175/JAM2206.1.

Zovko-Rajak, D., and T. P. Lane, 2014: The generation of nearcloud turbulence in idealized simulations. J. Atmos. Sci., 71, 2430-2451, https://doi.org/10.1175/JAS-D-13-0346.1. 